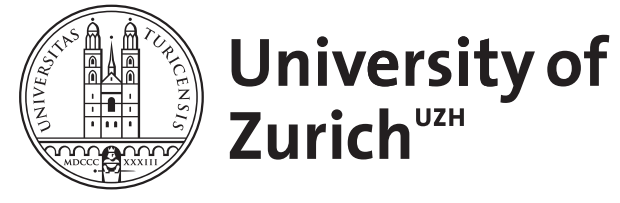
Archive

University of Zurich

University Library

Strickhofstrasse 39

CH-8057 Zurich

www.zora.uzh.ch

Year: 2019

\title{
Indiens "säkulare" Religion: Nationalistische Deutungen des Hinduismus
}

\author{
Malinar, Angelika
}

Posted at the Zurich Open Repository and Archive, University of Zurich

ZORA URL: https://doi.org/10.5167/uzh-177753

Book Section

Published Version

Originally published at:

Malinar, Angelika (2019). Indiens "säkulare" Religion: Nationalistische Deutungen des Hinduismus. In: Graf, Friedrich; Hartmann, Jens-Uwe. Religion und Gesellschaft : Sinnstiftungssysteme im Konflikt. Berlin: De Gruyter, 201-228. 


\section{Religion und Gesellschaft}

Sinnstiftungssysteme im Konflikt

Herausgegeben von

Friedrich Wilhelm Graf und Jens-Uwe Hartmann 


\section{Inhaltsverzeichnis}

\section{Vorwort - 1}

Friedrich Wilhelm Graf

Einleitung - 3

Monika Wohlrab-Sahr

Umkămpfte Săkularität - Streit um die Grenzen der Religion — 21

Horst Dreier

Recht und Religion: Zur (Un-)Möglichkeit religiös-weltanschaulicher Neutralităt des Staates -49

Christoph Türcke

Blasphemle und Aufklärung -83

Hans G. Kippenberg

Die globale Ermăchtigung aktiver Religlosităt durch das Allgemeine

Menschenrecht -93

Sebastian Schüler

"In der Welt, nicht von der Welt" - Simmels Konflikttheorie und die

Dynamiken religiőser Vergesellschaftung am Beispiel des evangelikalen

Kreationismus -119

e-ISBN (PDF) 978-3-11-058261-1

e-ISBN (EPUB) 978-3-11-058132-4

Llbrary of Congress Control Number: 2019946497

Bibllograflsche Information der Deutschen Natlonalbibliothek

Die Deutsche Nationalbibliothek verzeichnet diese Publikation in der Deutschen

Natlonalbibliografie; detaillierte bibliografische Daten sind im Internet liber

http://dnb.dnb.de abrufbar.

(c) 2019 Walter de Gruyter GmbH, Berlin/Boston

Druck und Bindung: $\mathrm{CPI}$ books $\mathrm{GmbH}$, Leck

Umschlagabbildung: jessicahyde / IStock / Getty Images Plus

Gudrun Krämer

Spannungsfelder: Der Islam, die Muslime und die săkulare

Moderne - 145

Mathias Rohe

Islam in den săkularen Rechtsstaaten Europas —167

Micha Brumlik

Die Siedler - ein Fall von jüdischem Fundamentalismus _-189 
mit den Mitteln kabbalistischer Spekulation kitten. Die im 16. Jahrhundert ent standene lurianische Kabbala, eine spekulative, mystische jüdische Geheimlehre geht von der Annahme aus, dass nach dem Schöpfungsakt, den die Kabbala als Zusammenziehung Gottes versteht, Funken göttlichen Lichts in die Gefangen schaft der Materie verbannt werden und dass es die Aufgabe der Menschheit im Allgemeinen, vor allem aber der Juden sei, die verbannten göttlichen Funken durch Mitzvot ${ }^{16}$ - die von der Tora gebotenen guten Werke - aus der Verbannung heimzuführen und damit einen Beitrag zur Heilung der Welt - hebräisch Tikkun Olam - zu leisten.

Raw Kook identifizierte das seiner Meinung nach gänzlich verkarstete und vernachlässigte Territorium Palästinas - das gleichwohl nicht wenigen arabischen Bauern jahrhundertelang zur Subsistenz gedient hatte - als einen wesentlichen Teil der gefallenen Welt, als eine jener Hüllen, die die gefallenen göttlichen Funken umschließt, weswegen seiner festen Überzeugung nach die landwirtschaftliche Pionierarbeit sogar atheistischer jüdischer Sozialisten den Beginn der eschatologischen Erlösung Israels anzeigte.

Im Sommer des Jahres 1967 freilich, im Zuge des Junikrieges, als israelische Truppen die Altstadt Jerusalems eroberten und der damalige Militärrabbiner Shlomo Goren am 7. Juni 1967 an der Klagemauer das Shofar, das traditionelle, sonst nur am Neujahr und am Versöhnungstag benutzte Widderhorn blies, nahm die Bedeutung des Landes auch für die religiös orthodoxen Zionisten eine andere Bedeutung an. Nunmehr waren es Teile der religiösen Jugendbewegung sowie nationalreligiöse Talmudschüler aus der Talmudschule des Sohnes von Raw Kook, die die Lehre verkündeten, dass Ostjerusalem, Hebron und das West jordanland jene Ländereien seien, die Gott dem Volke Israel versprochen habe und die es daher behalten und besiedeln müsse. Zwar gab und gibt es noch immer Diskussionen, ob Frieden nicht wichtiger als Land sei - ein sefardischer Oberrabbiner vertrat sogar die Meinung, dass Frieden als „Rettung des Lebens“ wichtiger sei als „Gebiete“, doch dies änderte nichts daran, dass die Synthese von jüdischem Fundamentalismus und säkularen Sicherheitsinteressen dazu führte, dass derzeit kaum noch an einen israelischen Rückzug aus dem Westjordanland zu denken ist. Die Folge ist nichts anderes als auf Dauer gestellte organisierte Friedlosigkeit. ${ }^{17}$

16 Abraham Isaak HaCohen Kook, Die Lichter der Tora / Orat Hatora, ed. Eveline GoodmannThaus et. al. Berlin: Walter de Gruyter, 1995, $99 \mathrm{f}$

17 Amira Hass, Morgen wird alles schlimmer. Berichte aus Palästina und Israel, aus dem Englischen von Sigrid Langhaeuser. München: C. H. Beck, 2006.

\section{Angelika Malinar \\ Indiens „säkulare“ Religion: Nationalistische \\ Deutungen des Hinduismus}

Seit den 1980er Jahren lässt sich in Indien der wachsende Einfluss eines politisierten Hinduismus in Form des Hindu-Nationalismus beobachten. Dieser hat inzwischen nicht nur auf politischer Ebene großen Einfluss gewonnen, sondern äußert sich auch immer wieder in gewalttätigen Attacken gegenüber den Anhängern von als "fremd“ deklarierten Religionen wie Islam und Christentum. ${ }^{1}$ Auf mehreren Ebenen gleichzeitig verfolgen verschiedene dem Hindu-Nationalismus zugehörenden Organisationen ihr Ziel, nämlich „Making India Hindu“.'2 Der Wahlsieg von Narendra Modi und seiner BJP (Bharatiya Janta Party; Indische Volkspartei) im Jahre 2014 stellte die politische Stärke dieser Gruppen erneut unter Beweis. ${ }^{3}$ Das deklarierte Ziel einer Durchsetzung hinduistischer Werte in Politik und Gesellschaft wurde nach der Wahl u. a. durch Schaffung eines „YogaMinisterium" bekräftigt. ${ }^{4}$ Eine internationale Anerkennung dieser Bestrebungen konnte die Regierung Modi darin sehen, dass auf ihre Initiative hin die Schaffung eines „International Yoga-Day“ durch die Vereinten Nationen beschlossen wurde (2015 erstmalig begangen).

Initiativen wie diese sowie die Berufung auf Hindu-Werte haben zuweilen dazu geführt, den Hindu-Nationalismus als eine rückwärtsgewandte Kraft anzusehen, die an alten Traditionen und Werten festhalte und sich dabei gegen wesentliche Elemente der Moderne wende, wie etwa den Säkularismus. Damit stelle sie nicht nur die weitere Modernisierung und Demokratisierung Indiens in Frage, sondern durch die politische Instrumentalisierung des Hinduismus auch die ihm zugeschriebene Toleranz und die ihm eigene Vielfalt spiritueller

Ebenfalls Ziel von Protesten und Gegenstand juristischer Verfahren wurden wissenschaftliche Forschungen zum Hinduismus und seiner Geschichte, die nicht den Ansichten von HinduNationalisten entsprechen. Offentliche Aufmerksamkeit erregte z. B. die Entscheidung des PenguinVerlages, das 2010 erschienene Buch The Hindus, an alternative history der amerikanischen Religionswissenschaftlerin Wendy Doniger nach Protesten vom indischen Markt zu nehmen.

2 So der Titel des 1998 von David Ludden herausgegebenen Sammelbandes zum Thema: Making India Hindu: Religion, Community and the Politics of Democracy in India. New Delhi: Oxford University Press, 2005 (reprint).

3 Von 1998-2004 hatte die BJP schon einmal regiert und mit Atal Bihari Vajpayee den Premierminister gestellt (dieser hatte bereits im Jahre 1996 für 16 Tage das Amt bekleidet).

4 So die in der Presse zirkulierende Abkürzung für das Ministry of Ayurveda, Yoga and Naturopathy, Unani, Siddha and Homeopathy (AYUSH). 
Heilswege. ${ }^{5}$ Es ist zwar unstrittig, dass eine Revitalisierung hinduistischer Werte auf verschiedensten Ebenen von den hindu-nationalistischen Organisationen angestrebt wird. Aber das bedeutet keineswegs, dass damit eine Ablehnung der Moderne als solcher einhergeht bzw. der Hindu-Nationalismus eine Abkehr von der Moderne bedeutet. Sowohl historisch als auch strukturell betrachtet ist vielmehr das Gegenteil der Fall. ${ }^{6}$ In einer historischen Perspektive ist der Hindu-Nationalismus sowohl Resultat von Kolonialismus und Modernisierungsprozessen als auch Reaktion darauf. Er ist aber nicht nur als ein Phänomen bzw. Produkt der Moderne ,modern' sondern er lässt sich auch als ein Projekt zur Uniformierung der religiösen Traditionen des Hinduismus mit Begriffen und Instrumenten der Moderne verstehen. ${ }^{7}$ Im Zuge der hindu-nationalistischen Kritik an einem dogmatisch-abgrenzenden ,westlichen" Religionsbegriff, der das Gegenteil von „wahrer" Religion sei, wird der Hinduismus einerseits als eine abgegrenzte und abgrenzende Nationalreligion gedeutet, anderseits als eine universelle, alle Religionen einschließende religiöse Lebensform präsentiert.

Im Zuge dieses Prozesses wird der Hinduismus nicht nur zu einer „modernen" Religion, die sich an demokratische und rechtsstaatliche Regeln hält, sondern er wird auch als die ideale Religion für die säkulare Moderne deklariert und der Welt empfohlen (zum Beispiel in Form des „Yoga-Day"). Die von den

5 Neben Hindu-Nationalismus wird in einigen akademischen Publikationen auch der Begriff Hindu-Fundamentalismus für diese Gruppen verwendet. In der Anwendung dieses Begriffs komm es zumeist zu Spezifizierungen, z. B. dass es sich nicht um einen „dogmatischen“, sondern einen „organisatorischen" Fundamentalismus handele; vgl. Sumit Sarkar, Beyond Nationalist Frames: Relocating Postmodernism, Hindu Fundamentalism, History. Bloomington: Indiana University Press, 2002, 200. Um die primär politische Stoßrichtung dieser Gruppen und ihrer Beanspruchung von Religion für die Propagierung ihrer Agenda zu betonen, werden sie auch als „Hindu Right" bezeichnet (z. B. Sarkar, Beyond Nationalist Frames, passim, Brenda Cossman, Ratna Kapur, „Secularism: Bench-Marked by Hindu Right". Economic and Political Weekly 31, No. 38 (1996), $2613-2617,2619-2627,2629-2630$.

6 Diese Sicht wird von zahlreichen Forschern gegenüber der Deutung des Hindu-Nationalismus als einer Abkehr von der Moderne oder eines religiösen revivalism vertreten, siehe z. B. Ashis Nandy, „The Politics of Secularism and the Recovery of Religious Tolerance“. Alternatives 13 (1988), 177-194; Tapan Basu et al., Khaki Shorts and Saffron Flags. A Critique of the Hindu Right. Hyderabad, u. a.: Orient Longman, 1993; Christophe Jaffrelot, The Hindu Nationalist Movement and Indian Politics. 1925 to 1990s. Strategies of Identity-Building, Implantation and Mobilisation (with special reference to Central India), London: Hurst, 1996.

7 Ashis Nandy deutet den Hindu-Nationalismus als eine "fanatische" Reaktion auf die westliche Moderne, die diese weniger ablehnt als vielmehr übertrumpfen will: „The zealot's one goal is to somehow defeat Western Man at his own game. [...] This is a crude way of describing a complex response, but it does convey that what passes as fundamentalism or revivalism is often only another form of Westernization [...]." Nandy, „The Politics of Secularism and the Recovery of Religious Tolerance", 186. hindu-nationalistischen Regierungen vorangetriebene Offnung der indischen Wirtschaft für den globalen Finanzkapitalismus, die Förderung der Entwicklung moderner Technologien usw. stehen nicht im Widerspruch zu diesem religiösen Programm, sondern sind Teil desselben. Der wirtschaftliche Aufschwung wurde von den beiden Premierministern, die die BJP bislang gestellt hat, zum Kerngeschäft erhoben. Atal Bihari Vajpayee machte 2004 mit dem Slogan „India Shining" (bhārat udaya) Wahlkampf. Narendra Modi profilierte sich als Ministerpräsident des wirtschaftlich stärksten indischen Bundesstaates Gujarat, bevor er die nationale Bühne betrat. Seine Wirtschaftspolitik wurde unter der Bezeichnung „Modi-nomics“ popularisiert. ${ }^{8}$ Er selbst wurde von seinen Anhängern sog. Börsen-Gurus vergleichbar - als „Magic Modi“ gefeiert. Die Einrichtung des o. g. „Yoga-Ministeriums“ steht keineswegs im Widerspruch dazu, und ist auch keine Konzession an einen religiösen Parteiflügel, sondern integraler Bestandteil seines Programms.

Wie die Moderne selbst ist auch der moderne Hindu-Nationalismus durch Widersprüche und Ambiguitäten charakterisiert, deren ganze Komplexität sich nach wie vor entfaltet und deren Ausgang keineswegs feststeht. Das gilt insbesondere für das Feld der Religion. Die klassische Modernisierungstheorie in der Soziologie etwa in der Formulierung von Max Weber postulierte einen zunehmenden Rückzug der Religion ins Private, deren Entpolitisierung und Säkularisierung. Wie in anderen Ländern auch kann man in Indien feststellen, dass es in der Moderne jedoch zu einer neuen Art der Politisierung von Religion gekommen ist, und zwar sowohl in der Kolonialzeit als auch nach der Unabhängigkeit im Jahre 1947. Der Hindu-Nationalismus ist keineswegs die einzige Manifestation dieser Politisierung, auch andere Religionen in Indien kennen nationalistische Bewegungen und politische Neudeutungen (z. B. Sikhs, Muslime). Zudem sahen bedeutende religiöse Führerpersönlichkeiten im modernen Indien ihre Religiosität als zutiefst politisch. Das vielleicht bekannteste Beispiel hierfür ist Mohandas K. („Mahatma“) Gandhi, dessen Verständnis von Religi-

8 Kurz vor der Wahl im Mai 2014 wurde ein von Modi autorisiertes Buch mit dem Titel Modinomics veröffentlicht, vgl. Sameeer Kochhar, Modinomics: Inclusive Economics, Inclusive Governance. Gurgaon: Skoch Media, 2014. Zum Verhältnis zwischen Hindu-Nationalismus und Kapitalismus bzw. Neoliberalismus siehe Thomas B. Hansen, „The Ethics of Hindutva and the Spirit of Capitalism". In Thomas B. Hansen, Christophe Jaffrelot (eds.), The BJP and the Compulsions of Politics in India. New Delhi: Oxford University Press, 1998; Stuart Corbridge, John Harriss, Reinventing India: Liberalisation, Hindu Nationalism and Popular Democracy. Cambridge: John Wilhey \& Sons, 2000; Shankar Gopalakrishnan, „Defining, Constructing and Policing a ,New India': Relationship between Neoliberalism and Hindutva“. Economic and Political Weekly 41 (2006), No. 26, 2803, 2805-2813. 
on einen Rückzug ins Private ausschloss. ${ }^{9}$ Eine persönliche Religiosität steht bei bedeutenden Vertretern des Hindu-Nationalismus nicht immer im Zentrum des politischen Engagements oder bildet den Ausgangspunkt dafür. Oft ist es der politische Kampf, der religiöse Dimensionen annimmt bzw. Religion instrumentalisiert. ${ }^{10}$ Das zeigt sich $u$. a. darin, dass die Religionspolitik verschiedener indischer Regierungen und deren Verständnis von Säkularismus im Zentrum hindu-nationalistischer Agitation standen. Dabei werden eine angebliche Schwäche und Uneinigkeit der Hindus als Ursachen dafür ausgemacht, dass diese von „fremden“ Minderheiten (sei es die Kolonialregierung, oder Christen und Muslime) unterdrückt seien. Diese Konstellation bestimmt den politischen Erfolg des Hindu-Nationalismus im unabhängigen, post-kolonialen Indien in erheblichem Maße und hat es ermöglicht, dass sich seine Vertreter heute als die wahren Hüter des indischen Säkularismus darstellen. Entsprechend ist der Hinduismus für sie nicht nur die „wahre“ indische Religion, sondern die moderne und säkulare Religion schlechthin. Diese Konstellation und die damit verbundenen Deutun gen des Hinduismus sind Gegenstand der folgenden Erörterungen. Zunächst wird der für den Hindu-Nationalismus zentrale Leitbegriff des „Hindu-Seins" bzw. "Hindutums" (hindutva) analysiert. Dieses Konzept ist der massgebliche Bezugspunkt verschiedener hindu-nationalistischer Organisationen und deren politisch-kultureller Programme und Praxisformen. Deren Auswirkungen im postkolonialen und gegenwärtigen Indien werden dann anhand der kontroversen Wechselwirkungen zwischen der säkularen Verfassung des indischen Staates und dem hindu-nationalistischen Programm diskutiert.

\section{Das „Hindu-Sein“ (hindutva) als politischer und religiöser Leitbegriff}

Die moderne Politisierung und Nationalisierung der religiösen Traditionen Indiens ist eng mit der britischen Kolonialherrschaft sowie der Prägung des neuen Begriffs „Hinduismus“ und den daran anschließenden Debatten verbunden. ${ }^{11}$

9 Siehe dazu Angelika Malinar, „Mohandas Karamchand Gandhi“. In Knud A. Jacobsen, Helene Basu, Angelika Malinar, Vasudha Narayanan (eds.) Brill's Encyclopedia of Hinduism, Volume V. Leiden: Brill, 2013, 542-551.

10 Einer der wichtigsten Ideologen des Hindu-Nationalismus, Vinayak Damodar Savarkar, ist dafuir ein Beispiel. Nandy, „The Politics of Secularism and the Recovery of Religious Tolerance“, $182 \mathrm{f}$, betont, dass Savarkar im Unterschied zu Gandhi ein Atheist war, der den Hinduismus zu seiner politischen Ideologie machte.

11 Bekanntlich ist der Begriff „Hinduismus“ Ende des 18. Jahrhunderts von christlichen Missionaren geprägt worden und hat seither nicht nur zu zahlreichen Innen- und Aussen-Definitionen
Diese Prozesse waren von den Zielen und Strukturen des Kolonialismus geprägt, der von Seiten der Kolonialherren als eine „zivilisatorische Mission“ dargestellt wurde, die Indien diene und daher tiefgreifende Eingriffe in die indische Gesellschaft rechtfertige (Bildung, Recht etc.). Dazu gehörten auch gezielte Maß nahmen zur Reform der indischen Gesellschaft und Religion, insbesondere des Hinduismus, der als besonders „rückständig“ galt. Das hat auf indischer Seite ganz unterschiedliche Reaktionen hervorgerufen, aber auch auf westlicher Seite zu unerwarteten Parteinahmen gegen den Kolonialismus und die Abwertung des Hinduismus geführt. Die unterschiedlichen Interpretationen des Hinduismus, die im 19. und frühen 20. Jahrhundert unternommen wurden, sind dafür Zeugnis. ${ }^{12}$ Sie alle sind auf die eine oder andere Weise mit der beginnenden Unabhängigkeitsbewegung verbunden und somit Teil des indischen Nationalismus, der sich mit der Gründung des Indian National Congress im Jahre 1885 erstmals politisch formierte. Der Ausdruck "indischer Nationalismus" ist ein Sammelbegriff für recht unterschiedliche Gruppierungen und politische Programme mit jeweils eigenen Vorstellungen darüber, was unter der indischen "Nation" zu verstehen ist und auf welchen Prinzipien ein unabhängiger indischer Staat in der Zukunft basieren soll. Im frühen 20. Jahrhundert war das, was heute als Hindu-Nationalismus bezeichnet wird, nur eine Variante des indischen Nationalismus und nur eine von mehreren nationalistisch-politischen Deutungen des Hinduismus. Die grundlegenden Formulierungen des hindu nationalistischen Kernprogramms stammen aus den 1920er und 1930er Jahren. ${ }^{13}$ In ihrer Konstruktion der „Hindu-Nation“ beziehen sich hindu-nationalistische Vordenker wie Vinayak Damodar Savarkar und M. S. Golwalkar u.a. auch auf zeitgenössische Staatstheorien. Neben Territorium und Abstammung machen sie die Hindu-Religion zum definierenden Element der Nation. ${ }^{14}$ Dabei wird der Hinduismus nicht nur von anderen Religionen abgegrenzt, sondern auch von

geführt, sondern auch zu politisch-kulturellen und rechtlichen Debatten; für einen Überblick siehe Angelika Malinar, Hinduismus. Göttingen: Vandenhoek \& Ruprecht (UTB), 2009, 13-25; für Beispiele akademischer Definitionen und Historisierungen siehe die Beiträge in John E. Llewellyn (ed.), Defining Hinduism. A Reader. London: Equinox, 2005.

12 Zum indischen Nationalismus siehe Partha Chatterjee, Nationalist Thought and the Colonia World: A derivative Discourse?. London: Zed Books, 1986; zu Neuformlerungen im Hinduismus siehe Malinar, Hinduismus.

13 Für einen Uberblick über programmatische Texte und Autoren siehe den von Christophe Jaffrelot herausgegebenen reader: Hindu Nationalism - A Reader. Princeton: Princeton University Press, 2007.

14 Wie Benedict Anderson in seiner klassischen Studie zum Nationalismus (Imagined Communities. London: Verso, second revised edition 1991 [1983]) herausgestellt hat, beruht die Idee von Nation auf verschiedenen Konstruktionen dessen, worin eine Nation besteht. Territorium, Sprachzugehörigkeit, Abstammung, Religion etc. wurden als Kriterien zur Bestimmung von „Nation“ 
einem als „westlich“ deklarierten Religionsbegriff. Um die Argumentationsmuster und Agitationsformen der Hindu-Nationalisten einordnen zu können, ist es notwendig, die in den grundlegenden Texten vorgebrachten Definitionen und Deutungsmuster etwas näher zu betrachten.

Die hindu-nationalistische Ideologie wurde zu Beginn der 1920er Jahre in paradigmatischer Weise zunächst von Vinayak Damodar Savarkar (1883-1966) formuliert. Vor allem durch den von ihm lancierten neuen Begriff „Hindutva“, Hindu-Sein bzw. Hindutum, prägte er das politische Programm nachhaltig. Savarkar formulierte seine Ansichten während seiner Inhaftierung (wegen aufrührerischer Aktivitäten gegen die Kolonialherrschaft) auf den Andamanen-Inseln in einem auf Englisch geschriebenen Traktat, das 1923 unter dem Titel Essentials of Hindutva publiziert wurde. ${ }^{15}$ Der Text kann u. a. als eine direkte Reaktion auf das Scheitern des von Gandhi geführten Kampfes gegen die Kolonialherrschaft gelesen werden. Gandhi sah sich 1922 gezwungen, seine „non-cooperation“Kampagne nach Gewaltausbrüchen abzubrechen. Sowohl innerhalb als auch außerhalb des Indian National Congress wurden Alternativen zu Gandhis Politik propagiert. Ein Sammelbecken für diejenigen, die im Kampf gegen die Kolonialherrschaft darauf setzten, dass sich die Hindus auf ihre Stärke und ihre religiösen und kulturellen Werte besinnen, war die 1915 gegründete Hindu Mahāsabha $\bar{a}^{16}$ Ihre Wortführer kritisierten Gandhis Ansicht, dass nur ein friedfertiger und toleranter Hindu ein wirklicher Hindu sei. Nach dem Scheitern von Gandhis Kampagnen verstärkten sie ihre Bemühungen um die „Einheit der Hindus“" (hindu sañgāthan). Savarkar war in der Hindu Mahāsabhā engagiert und fungierte in den 1930er Jahren auch als deren Präsident. Er war auch eng verbunden mit einer anderen hindu-nationalistischen Organisation, die 1925 gegründet wurde und zur Kaderschmiede des Hindu-Nationalismus wurde, der Rāstrīya Svayamsevak Sangh (RSS), die „Nationale Vereinigung der freiwilligen

diskutiert bzw. von sich gründenden Nationalstaaten herangezogen. Daher sind nach Anderson Nationen „,imagined communities“, deren Realität dann in politischen und sozialen Prozessen und Konflikten auszuhandeln ist.

15 Zu Savarkars Biographie siehe Dhanajay Keer, Veer Savarkar. Bombay: A. V. Keer, 1950. Für den politischen Kontext der Veröffentlichung und Savarkars Kritik an Gandhi siehe Janaki Bakhle, "Country First? Vinayak Damodar Savarkar (1883-1966) and the Writing of Essentials of Hindutva“. Public Culture 22,1 (2010), 149-186.

16 Zur Geschichte dieser Vereinigung siehe Prabhu Bapu, Hindu Mahasabha in Colonial North India, 1915-1930. Constructing Nation and History. London: Routledge, 2013; zu deren Verhältnis zu anderen hindu-nationallstischen Organisationen siehe Basu et al., Khaki Shorts and Saffron Flags Gyanendra Pandey, "Which of us are Hindus?". In Ders. (ed.), Hindus and Others: The Question of Identity in India Today. New Delhi: Viking, 1993, 238-272; Jaffrelot, The Hindu Nationalist Movement and Indian Politics.
Helfer". 1936 wurde der RSS durch die Frauenorganisation Rāstrasevikä Samiti erweitert. Gründer und erster Führer der neuen Organisation war Keshav Baliram Hedgewar (1889-1940). Sein Nachfolger wurde 1940 Madhav Sadashiv Golwalkar (1906-1973), der auch zur weiteren Ausformulierung der Hindutva-Ideologie beitrug.

Die Erklärung des Wortes „Hindu“ und die Definition des „Hindu-Seins“ als Kernelement der indischen Nation und Kultur sind zentrale Anliegen von Savarkars Hindutva-Traktat. Er sieht den ersten Schritt der Befreiung der Nation darin, sich als „Hindu“ zu begreifen und zu bezeichnen. Dazu gilt es, die wahre Bedeutung des Wortes zu erkennen und von missverständlichen Interpretationen zu reinigen. Es handele sich nämlich um einen Namen, der eins sei mit der Sache selbst, dem Hindu-Sein. ${ }^{17}$ In der Erklärung dieses Namens grenzt er ihn einerseits von der im 19. Jahrhundert neu entwickelten Bedeutung von "Hindu“ im Sinne von „Anhänger des Hinduismus" ab, und andererseits vom Wort bhäratīya, das neben „Hindu“ (vor der Erfindung des Wortes „Hinduismus“ als geographische Bezeichnung gängig) im Sinne von „indisch“ zur Bezeichnung der Nationalität dient. Für Savarkar ist das Wort bhāratīya als Bezeichnung für die Hindu-Nation weniger nützlich, da es wegen seiner primär geographischen Bedeutung auch Christen und Muslime einschließt, welche jedoch nicht die von ihm definierten Kriterien des Hindu-Seins erfüllten. ${ }^{18}$ Beide Abgrenzungen ermöglichen Savarkar das Wort „Hindu“ in einer Weise zu definieren, die es

17 Mit dieser These beginnt Savarkar sein Traktat, indem er die Auffassung, dass Namen nu beliebige Bezeichnungen für die Sache sind, anhand der Zeile „What is in a name?" aus Shakespeares Romeo und Julia illustriert. Demgegenüber bekundet er sein „idolatrous attachment“ zum Namen „Hindu“. Vinayak Damodar Savarkar, Essentials of Hindutva (reprint as: Hindutva: Who is a Hindu? (1923)). Bombay: S. S. Savarkar, 51969. Die darin enthaltene Polemik gegen den englischen Bildungskanon und die christliche Kritik am hinduistischen Bilderkult wird hier sowie an anderen Stellen rhetorisch geschickt lanciert. Die Reklamation des Namens prägt auch an anderen Stellen die Struktur des Textes, etwa in der namentlichen Aufzählung von Personen und Gruppen, deren Existenz das „heilige Mutterland“ als geographische, historische und kulturelle Einheit lebendig werden lässt. Das wird ergänzt durch eine Kompilation von Zitaten und Verweisen. Bakhle stellt fest, dass Savarkars deklamatorische Rhetorik darauf ziele, einen affektiven bzw. „monogamen Bezug zu einer sakralisierten Hindu-Nation zu progagieren. Janaki Bakhle, „Country First? Vinayak Damodar Savarkar (1883-1966) and the Writing of Essentials of Hindutva“. Public Culture 22,1 (2010), 149-186. Pandey vermerkt die politische Instrumentalisierung von Vorstellungen einer mystischen Einheit von Wort und Gegenstand in den devotionalen Traditionen der Hinduismus (bhakti) und im Sufismus. Pandey, „Which of us are Hindus?", 247.

18 Savarkar wendet sich auch gegen diejenigen, die das Wort „Arya“ (Arier) als Selbstbezeichnung an Stelle von „Hindu“" propagieren. Savarkar, Essentials of Hindutva, $76 \mathrm{ff}$. Stattdessen verwendet er "Arya" in einer Weise, die nicht mehr auf ausschließlich auf die vedische Religion rekurriert (wie es etwa der Hindu-Reformer Dayananda Sarasvati tat, der 1875 den Arya Samaj gründete), sondern auch nicht-vedische Religionen einschließt (ebd., 32 f.). Auch andere Nationalisten hatten sich 
erlaubt, die Einheit der Hindus so zu beschreiben, dass einerseits eine innere Diversität und Vielfalt anerkannt werden kann, und andererseits Gruppen und Personen identifiziert werden können, die nicht zur Hindu-Nation zugehören sollen. ${ }^{19}$ Eines der größten Missverständnisse sieht Savarkar darin, dass man den Namen „Hindu“ für eine Fremdbezeichnung halte, die kein Pendant im Sanskrit habe, obgleich es sich dabei um die ursprüngliche Bezeichnung für die Bewohner Indiens handele. Er weist darauf hin, dass das Wort "Hindu“ eine Variante des Sanskrit-Wortes sindhu ist, die Bezeichnung für den Fluss Indus. Daher lautet die älteste Bezeichnung für die Bevölkerung, die in dieser Region lebte, die sindhus. In indischen Regionalsprachen könne ein "s" durch "h" substituiert werden, so dass aus „sindhu“, „hindu“ werde. ${ }^{20}$ Daher handele es sich bei der Vorstellung, dass „Hindu“ eine Fremdbezeichnung sei, um eine "stupid notion", die verschwinden müsse: „The first result of our enquiry is to explode the baseless suspicion which has crept into the minds of some of our well-meaning but hasty countrymen that the origin of the words Hindu and Hindusthan is to be traced to the malice of the Mohammedans! [...] Long before Mohammad was born, [...] this ancient nation was known to ourselves as well as to the foreign world by the proud epithet Sindhu or Hindu and Arabians could not have invented this term, any more than they could have invented the Indus itself. They simply learnt it from the ancient Iranians, Jews, and other peoples. “21 Die Ursprünglichkeit und die allgemeine Anerkennung des Namens außerhalb Indiens erklären zudem, warum sich das Wort bhäratavarșa für Indien und auch davon abgeleitete Bezeichnungen (wie o.g. bhäratiya) nicht wirklich durchgesetzt hätten. ${ }^{22}$ Der im Wort bhärat enthaltene Bezug zu einem Herrscher eigne

gegen die Vorstellung von einem indo-europälschen „Arlertum“ gewendet, auf dessen Grundlage Gemeinsamkeiten zwischen Briten und Indern konstruiert wurden, siehe dazu Joan Leopold, „The Aryan Theory of Race in India, 1870-1920: Nationalist and Internatlonalist Visions". The Indian Economic and Social History Review 7 (1970), 271-297; und Christophe Jaffrelot, „The Idea of the Hindu Race in the Writings of Hindu Nationalist Ideologues in the 1920 and 1930s: A Concept between two Cultures". In Peter Robb (ed.), The Concept of Race in South Asia. New Delhi: Oxford University Press, 1995, 327-354, hier 340-343.

19 Vgl. auch Golwalkars Erklärung, warum „Hindu“ und nicht bhäratīya (indisch) die richtige Bezetchnung für die Nation sei; Madhav Sadashiv Golwalkar, Bunch of thoughts. Bangalore Vikrama Prakashan, ${ }^{4} 1968,97-99$. Für eine Diskussion zeitgenössischer Verwendungsweisen und Definitionen dieser Worte siehe Pandey, „Which of us are Hindus?", 244-246.

20 Savarkar, Essentials of Hindutva, $6 \mathrm{f}$. Er verweist auf altiranische Quellen (Avesta) und indische Regionalsprachen (sog. Prakrits). Diejenigen, die ,keep constantly harping on the fact that this word Hindu is not found in Sanskrit“", weist er wie folgt zurück: „it is ridiculous to expect a Prakrit word in classical Sanskrit“ (ebd., 71).

21 Savarkar, Essentials of Hindutva, $70 \mathrm{f}$,

22 Diese Bezeichnung leitet sich vom in den klassischen Quellen erwähnten König Bharata und sich kaum, um die affektive Bindung der Hindus an ihr Land auszudrücken: „The Emperor Bharat is gone and gone also is many an emperor as great! - but the Sindhu goes on forever; forever inspiring and fertilizing our sense of gratitude, vivifying our sense of pride, renovating the ancient memories of our race - a sentinel keeping watch over the destinies of our people. It is the vital spinal cord that connects the remotest past to the remotest future.“23 Daher sei „Hindu“ die Bezeichnung, die das Gefühl des „Hindu-Seins" erzeuge und bezeuge, indem sie das Land zwischen dem Indus (sindhu) und den Meeren (ebenfalls in Sanskrit: sindhu) benennt. ${ }^{24}$

Damit wird der gesamte indische Subkontinent zum Staatsgebiet (rāstra) der Hindus erklärt und zu einem Kriterium des „Hindu-Seins“ erhoben. Als zweites Kriterium nennt Savarkar die Zugehörigkeit zur Abstammungsgemeinschaft bzw. „race“ (jāti) der Hindus. Die Hindus seien „a race with common blood“, „a born brotherhood". Das zeige sich darin, dass sie sich als eine Familie von Kasten organisiert haben, in die auch "outsiders" aufgenommen werden können. ${ }^{25}$ Das Kastensystem wird hier als organisches Modell einer hierarchisch organisierten Gesellschaft angesehen, deren Mitglieder durch das ihnen gemeinsame Blut verbunden seien. ${ }^{26}$ In seiner Analyse der Verwendung des Wortes „race“ bei Savarkar und anderen Hindu-Nationalisten stellt Christophe Jaffrelot fest, dass hier weniger ein biologischer Rassismus propagiert werde als ein sozialer. Das Kastensystem wird zur Erscheinungsform einer eher sozial und affektiv als eugenisch-biologisch gedeuteten Hindu-Blutsgemeinschaft. ${ }^{27}$ Diejenigen, die ursprünglich nicht Teil dieser Gemeinschaft sind, werden auf der untersten Ebene

seinen Nachkommen (bhārata-s) ab, und auch die indische Republik trägt den Namen „Bhārat“. Sakralgeographisch wird bhäratavarsa in den indischen Quellen als eine kosmische Region be schrieben, die vom Himalaya und dem Ozean begrenzt wird sowie einige besondere Merkmale aufweist, siehe Malinar, Hinduismus, $\mathbf{1 7 0 - 1 7 5}$.

23 Ebd., 31.

24 Diese Doppelbedeutung von sindhu wird von Savarkar als ein weiterer Vorteil gewertet: The word Sindhu in Sanskrit does not only mean the Indus but also the Sea - which girdles the southern peninsula - so that this one word Sindhu points out almost all frontiers of the land at a single stroke. [...] the epithet Sindhusthan calls up the image of our whole Motherland: the land that lies between Sindhu and Sindhu - from the Indus to the Seas." Savarkar, Essentials of Hindutva, $31 \mathrm{f}$.

25 Ebd., 85-86.

26 In einer refrainartigen Deklamation beschwört Savarkar diese Blutsverwandtschaft durch die Auflistung unterschiedlicher Kasten: „Some of us were Aryans and some Anaryans; but Ayars and Nayars - we were all Hindus and own a common blood. Some of us are Brahmans and some Namashudras or Panchamas; but Brahmans or Chandalas - we are all Hindus and own a common blood. Some of us are Daxinatyas and some Gauds; but Gauds or Saraswatas - we are all Hindus and own a common blood." Savarkar, Essentials of Hindutva, 89.

27 Jaffrelot, „The Idea of the Hindu Race in the Writings of Hindu Nationalist Ideologues in 
der Hierarchie angesiedelt. Das Ausmaß ihrer Integration bzw. Aufstiegsmöglich keiten richte sich danach, wie sehr sie sich den Werten der Kastenhierarchie anpassen. Es handele sich hier um einen Rassismus, der eher auf die soziale und kulturelle Unterwerfung des „Anderen“ ziele als auf dessen Ausrottung. ${ }^{28}$ Die affektive Grundierung der Deutung der „Hindu race“ bei Savarkar zeigt sich auch darin, dass die Vielfalt religiös-philosophischer Positionen und Traditionen ebenfalls zu einem Bezugspunkt für das Gefühl der Zugehörigkeit und inneren Zusammengehörigkeit erhoben wird: „Some of us are monists, some, pantheists; some theists and some atheists. But monotheists or atheists - we are all Hindus and own a common blood. We are not only a nation but a Jati, a born brotherhood. Nothing else counts, it is after all a question of heart. We feel that the same ancient blood that coursed through the veins of Ram and Krishna, Buddha and Mahavir, Nanak and Chaitanya, Basava and Madhava, of Rohidas and Tiruvelluvar courses throughout Hindudom from vein to vein, pulsates from heart to heart. ${ }^{، 29}$ Eine Einheitsreligion mit einem klar definierten Spektrum von Lehren

the 1920 s and 1930s", 333, Anm. 26, weist daraufhin, dass Savarkar das Wort „race“ weniger im Sinne von „Rasse“ verwendet als eher - wie im zeitgenössischen Diskurs üblich - im Sinne von "nation". Das zeige sich auch in der Verwendung des Sanskrit- bzw. Hindi-Wortes jāti, das hier im Sinne einer zoologischen „Spezies“ zu verstehen sei (ebd., 348). Ungeachtet der Kenntnis solcher Taxonomien bei Savarkar bleibt festzuhalten, dass er für sein Verständnis von jăti auf keine indischen Quellen verweist. M. S. Golwalkar jedoch zitiert in einer 1939 veröffentlichten Schrift zum Thema die Definttion von jāti aus dem Nyāyasūtra des Gautama (ca. 2. Jh. v. Chr. - 2. Jh n. Chr.), einem Grundtext der klassischen indischen Philosophie. Dadurch möchte er nachweisen, dass bereits Gautama das Konzept der „Nation“ vollumfassend definiert habe: „Race means those people who have a common origin and common fellow feeling, i. e. are related together by common traditions and naturally by common aspirations." Madhav Sadashiv Golwalkar, We or our Nationhood defined. Nagpur: Kale, ${ }^{4} 1947,62 \mathrm{f}$. Golwalkar bezieht sich dabei jedoch auch nicht auf „specles" als (eine durchaus) mögliche Bedeutung von jāti im Nyāyasūtra. Vielmehr setzt er sich vor allem mit westlichen Definitionen von „Nation“ auseinander und definiert die HinduNation mit Hilfe der folgenden fünf Faktoren „Geographical (country), Racial (race), Religious (religion), Cultural (culture), and Linguistic (language)“ (ebd., 23). Zur Bedeutung zeitgenössischer Staatstheoretiker für diese Definition siehe Jaffrelot, „The Idea of the Hindu Race in the Writings of Hindu Nationalist Ideologues in the 1920 and 1930s", 343-346.

28 Jaffrelot, "The Idea of the Hindu Race in the Writings of Hindu Nationalist Ideologues in the 1920 and 1930s", 344, 354. Zum Verhältnis der Hindu-Nationalisten zum Nationalsozialismus in Deutschland und zur faschistischen Ideologie siehe auch Sumit Sarkar, „The Fascism of the Sangh Parivar". Economic and Political Weekly 28, No. 5 (1999), 163-167. Die seit den 1980er Jahren zu beobachtende rhetorische Aufrüstung sowie die zunehmende Militanz und Gewaltbereitschaft gegenüber Minderheiten und zu "Feinden" deklarierten Personen und Gruppen hat dazu geführt, dass der Hindu-Nationalismus auch als faschistisch beschrieben wurde, siehe z. B. den genannten Titel von Sarkar und Sucheta Mazumdar, „Women on the March: Right-Wing Mobilization in Contemporary India“. Feminist Review 49 (1995), 1-28.

29 Savarkar, Essentials of Hindutva, 89. und Praktiken und einem begrenzten Repertoire von religiösen Lehrern sei dem Hindu-Sein fremd. Charakteristisch sei vielmehr die Zuneigung, die Hindus zu der von ihnen selbst generierten religiösen Vielfalt hegen. Die Hindus als Nation verkörperten die Einheit dieser Vielfalt.

Der immer wieder von Savarkar betonte affektive Bezug, die gefühlte $\mathrm{Zu}$ gehörigkeit zum „Hindu-Sein“, eröffnet auch für „outsiders“ die Aufnahme in die Hindu-Nation bzw. führt für diejenigen, die sich davon entfernen, zum Ausschluss. ${ }^{30}$ Das führt in die Konstruktion des „Hindu-Seins“ ein Element von Wahl und individueller Neigung ein, das ermöglicht, was Jaffrelot als „subjective raciality" bezeichnet und als einen Widerspruch in sich ansieht. ${ }^{31}$ Diese widersprüchlich anmutende Konstruktion passt jedoch zu der stark ausgeprägten kulturalistisch-affektiven Deutung der Abstammungsgemeinschaft und der Reklamation des Hinduismus als Religion der Vielfalt. Diese Konstruktion ist ein wichtiges Element der hindu-nationalistischen Ideologie. Es wird auch gegenwärtig von den Hindutva-Organisationen dazu verwendet, den Status von religiösen und sozialen Minderheiten als Folge einer Wahl (,choice“) zu interpretieren, die sie auch revidieren können. ${ }^{32}$

30 Beide Konstellationen werden von Savarkar durchgespielt. Zum einen wird Hindus, die sich durch Konversion zum Christentum oder Islam vom Hindu-Sein abgewendet haben, die Zugehörigkeit zur Hindu-Nation abgesprochen, obwohl sie dem „Blut nach" Hindus sind. Savarkar, Essentials of Hindutva, $110 \mathrm{f}$. Zum anderen können „foreigners" der Hindu-Nation zugerechnet werden, obwohl sie kein Hindu-Blut in sich tragen, wenn sie sich durch ihre Liebe zur HinduReligion und die Annahme der Hindu-Kultur als Hindus erweisen. Als Beispiele nennt er die Engländerinnen und bekennende Hindus Margaret Noble - bekannt als Sister Nivedita - (18671911) und Annie Besant (1847-1933); siehe Savarkar, Essentials of Hindutva, 130 f. Zu Besant und ihrer Deutung des Hinduismus siehe Angelika Malinar, „Karmic histories and the synthesis of East" and "West'. Annie Besant on Hinduism". In Angelika Malinar, Simone Müller (eds.). Asia and Europe - interconnected: Agents, Concepts and Things. Wiesbaden: Harrassowitz, 2018, 55-89, 31 Jaffrelot, „The Idea of the Hindu Race in the Writings of Hindu Nationalist Ideologues in the 1920 s and 1930s", 343.

32 Bakhle betont ebenfalls das Element der "choice", bezieht dieses aber auf den Nationalismus als solchen (während es in Savarkas Text um die Definition des Hindu-Seins geht und damit um die von Jaffrelot herausgestellte Paradoxie einer "subjective raciality"). Gleichwohl benennt sie die Funktion dieses Arguments treffend: „Nationalism, in a curious twist, now becomes a matter of choosing to love, and in making it so, Savarkar allows for all future generations of militant Hindu nationalists to use the modern concept of political choice as their alibi for prejudice." Bakhle, "Country First? Vinayak Damodar Savarkar (1883-1966) and the Writing of Essentials of Hindutva“" 179. Das Element von "choice" wird im Zuge der Akzeptanz neoliberaler Parameter auf Seiten von Hindu-Nationalisten seit den späten 1980er Jahren (siehe Gopalakrishnan, „Defining, Constructing and Policing a ,New India') sowie im Hinblick auf die von ihnen betriebene „AntiKonversion"-Gesetzgebung erweitert und neu konfiguriert (siehe unten). 
Vor diesem Hintergrund erläutert Savarkar das dritte Kriterium von Hindutva: die Teilhabe an samskrti, der Kultur bzw. „civilization“ der Hindus, im Sinne aller ihrer geistigen Errungenschaften. Das Wort samskrti wird von Savarkar in einen engen Zusammenhang mit dem Sanskrit als die alle Hindus einende Sprache gestellt, deren „sister-languages“ alle auf sie zurückgingen. ${ }^{33}$ In diesem Zusammenhang diskutiert Savarkar auch die Religion und den Hinduismus. Wie bereits erwähnt, bedeutet für ihn das Wort „Hindu“ weit mehr als „Anhänger des Hinduismus“. Vielmehr ist die Religion ein Teil des Hindu-Seins. Der Begriff „Hinduismus“ im Sinne eines spezifischen Spektrums von Lehren und Praktiken dürfe nicht das Wort „Hindu“ usurpieren. Zumal „Hinduismus“ von allen Worten das wirklich "fremde" sei, das viel Verwirrung und Entfremdung unter den Hindus stifte: „if there be really any word of alien growth it is this word Hinduism and so we should not allow our thoughts to get confused by this new-fangled term. ${ }^{\text {"34 }}$ Es gehöre zur westlichen Konstruktion von Religionen als voneinander abgegrenzten „ism-s“, von der Savarkar hofft, dass sie bald der Vergangenheit angehört. Erst dann können Religionen werden, was sie sein sollten: „the common fund of eternal principles that lie at the root of all that are a common foundation on which the Human State majestically and firmly rests“. 35

Hinduismus ist für Savarkar nicht nur ein fremdes Wort, sondern auch ein „sectarian term“ ${ }^{36}$ an dessen Definition er kein Interesse hat. Viel wichtiger sei es zu erklären, was ein Hindu ist, um zu bestimmen, wer in religiöser Hinsicht ein Hindu sei: „Hinduism means the system of religious beliefs found common amongst the Hindu people. And the only way to find out what those religious beliefs of the Hindus are, i. e., what constitutes Hinduism, you must first define a Hindu. ${ }^{\star 37}$ Nicht die eine oder andere Definition von Hinduismus dürfe bestimmen, wer ein Hindu ist, sondern vielmehr definiere das „Hindu-Sein" den Hinduismus: „Hinduism is only a derivative, a fraction, a part of Hindutva. “38 Diese Tatsache werde in der Regel von denjenigen vergessen, die versuchen, den Hinduismus zu definieren. Das führe regelmäßig dazu, dass die eine oder andere Gruppe, Lehre oder Praxis ausgeschlossen werden müsse, um zu einer Definition von Hinduismus zu kommen. Daher komme es zu ganz unterschiedli-

33 Auch Golwalkar betont die auf dem Sanskrit beruhende linguistische Einheit der HinduNation. Golwalkar, We or our Nationhood defined, $51 \mathrm{f}$.

34 Savarkar, Essentials of Hindutva, 81.

35 Ebd., 83.

36 Ebd., 4 .

37 Ebd., 103

38 Ebd. 4 chen Definitionen und endlosen Debatten darüber. Manche zögen daraus sogar den Schluss, dass es gar keine Hindus gäbe. ${ }^{39}$

Ein weiteres Problem besteht nach Savarkar darin, dass manche versuchen, die mehrheitlich praktizierten Formen des Hinduismus zur Norm zu erheben und als „orthodox" zu bezeichnen. Dabei handele es sich jedoch um eine unangebrachte Wortverwendung: „Hinduism is a word that properly speaking should be applied to all the religious beliefs that the different communities of the Hindu people hold. But it is generally applied to that system of religion which the majority of the Hindu people follow. " ${ }^{40}$ Das führe jedoch $\mathrm{zu}$ einer nicht hinnehmbaren Verengung: „if you identify the religion of the Hindus with the religion of the majority only and call it orthodox Hinduism, then the different heterodox communities being Hindus themselves rightly resent this usurpation of Hindutva by the majority as well as their unjustifiable exclusion. " ${ }^{41}$ Daher sollte auch eine mehrheitlich praktizierte Form des Hinduismus (sog. sanātana dharma) nur als eine seiner Varianten gelten und nicht als Norm setzend. ${ }^{42}$ Hinduismus bzw. „Hindu dharma“ (Hindu-Religion) sollte daher im Sinne eines generischen Begriffs verwendet werden, um die verschiedenen religiösen Traditionen der Hindus insgesamt anzusprechen. ${ }^{43}$ Konkret zeige sich die religiöse Zusammengehörigkeit aller Hindus darin, dass für sie - im Gegensatz zu den Angehörigen aller anderen Religionen - Indien nicht nur das Vater- bzw. Mutterland ist, sondern auch das „Heilige Land“.

Auf dieser Grundlage kommt Savarkar gegen Ende des Traktats zu folgender Definition von „Hindu“, die er in einem Sanskrit-Vers zusammenfasst, ${ }^{44}$ den er in einer Ansprache anlässlich der Zusammenkunft der Hindu Mahāsabhā im Jahre

\section{Ebd.}

40 Ebd., 105.

41 Ebd., 106

42 Savarkar bezieht sich hier u. a. auf diejenigen Gruppen, die sich als Bewahrer und Verteidiger der Tradition gegenüber den modernen hinduistischen Reformbewegungen sehen (von denen einige z. B. die Bllderverehrung ablehnen). Diese sahen sich als Hüter des sog. sanātana dharma, der "ewigen Religion" und wurden entsprechend als "Sanātanis" bezeichnet. Zur Geschichte des Ausdrucks sanātana dharma als Ưbersetzung für „Hinduismus" sowie der Verwendung von Sanskrit dharma als Ubersetzung für "religion" siehe Wilhelm Halbfass, India and Europe: An Essay in Understanding. Albany: State University of New York Press, 1988. Zu den Positionen und Organisationen der Sanātanis siehe John Zavos, „Defending Hindu Tradition: Sanatana Dharma as a Symbol of Orthodoxy in Colonial India“. Religion 31 (2001), 109-123. Mohandas K. Gandhi hat sich auch als Sanātani Hindu bezeichnet und sein Verständnis von sanātana dharma dargelegt, siehe dazu Malinar, „Mohandas Karamchand Gandhi“.

43 Ebd., 107.

44 Der Text lautet: „āsindhusindhuparyatā yasya bhāratabhūmikä / pitṛbhūh punyabhūś caiva sa vai hindur iti smrtah". Savarkar, Essentials of Hindutva, 116 
1937 wie folgt übersetzt: „Everyone who regards and claims this Bharatbhoomi from the Indus to the Seas as his Fatherland and Holyland is a Hindu. "45 Savarkar erläutert diese Definition zusammenfassend wie folgt: „Hindudom is bound and marked out as a people and a nation by themselves not by the only tie of a common Holyland in which their religion took birth but by the ties of a common culture, a common language, a common history and essentially of a common fatherland as well. It is these two constituents taken together that constitute our Hindutva and distinguish us form any other people in the world. " ${ }^{46}$ Diese Definition hat die unmittelbare Konsequenz, dass eigentlich nur die Hindus die indische Nation darstellen, sie allein lieben das Land und die Kultur zwischen „Indus und den Meeren“ in einer umfassenden und ausschließlichen Form. Die Muslime mögen zwar in Indien geboren sein, eine indische Sprache sprechen usw., aber ihr Heiliges Land befände sich außerhalb Indiens. Aus diesem sakralgeographischen Sachverhalt leitet Savarkar eine Art nationaler Unzuverlässigkeit der muslimischen Inder ab, die aufgrund ihrer Zugehörigkeit zu einer nichtindischen Religion nicht vollständig den Interessen der Nation dienen können und von daher einen potentiellen Gefahrenpunkt abgeben: „Their [the Muslims A. M.] love towards India as their motherland is but an handmaid to their love for their Holyland outside India. Their faces are ever turned towards Mecca and Madina [sic!, i. e. Medina]. But to the Hindus Hindusthan being their Fatherland as well as their Holyland, the love they bear to Hindusthan is undivided and absolute. ${ }^{\text {"47 }}$

Dieser ideologische Rahmen und die damit verbundenen Elemente des „Hindu-Seins“ werden in den folgenden Jahrzehnten mit einer zunehmenden Reklamation des Hinduismus und seiner religiösen Traditionen als das wahre kulturelle Erbe Indiens weiter ausgebaut. Eine wichtige Rolle spielt dabei Madhav Sadashiv Golwalkar (1906-1973), der, wie bereits erwähnt, 1940 die Führung des o.g. RSS übernahm. Er propagiert ein Hindutum der Stärke und erhebt in seiner Definition der Hindu-Nation die Religion zu einem zentralen Element. ${ }^{48}$ Beides wieder gross und stark zu machen, wird zu einer heiligen Aufgabe erhoben. Im Vorwort zu seiner 1939 veröffentlichten Abhandlung We or Our Nationhood defined deklariert er diese als ,a humble offering at the holy feet of the Divine Mother the Hindu Nation - in the hope that She will graciously accept this worship". ${ }^{49}$

45 Vinayak Damodar Savarkar, Hindu Rashtra Darshan. A Collection of Presidential Speeches delivered from the Hindu Mahasabha Platform. Bombay: Khare, 1949, 4

46 Ebd.

47 Savarkar, Hindu Rashtra Darshan,14.

48 Zu Golwalkars Konzeption der Hindu-Nation siehe auch Pandey, „Which of us are Hindus?".

49 Golwalkar, We or our Nationhood defined, 4.
Damit wird die schon bei Savarkar vorgenommene Sakralisierung Indiens in die kultische Verehrung der (neuen) Göttin Bhārat Mātā (Mutter Indien) überführt, die ein wichtiges Element der von den Hindu-Nationalisten propagierten „Liebe zur Nation" (räștrabhakti) ist. ${ }^{50}$ Die Religion rückt bei Golwalkar ins Zentrum seines Verständnisses von Hindu-Sein: „in Hindusthan Religion is an all absorbing entity [...] it has become eternally woven into the life of the Race and forms as it were its very soul. [...] Naturally, therefore we are what our great Religion has made us. "51 Wie Savarkar kritisiert auch Golwalkar das westliche Religionsverständnis, das durch die Vorstellung von allgemeingültigen Lehren geprägt sei. Diese würden „dogmatically forced down the throats of one and all, without any considerations for individual aptitudes"..$^{52}$ Bestenfalls gehe es noch um Religion im Sinne einer individuellen Beziehung zwischen Gott und Glaubenden. Eine Konsequenz der westlichen Auffassung sei, dass man nun propagiere, dass Religion vollkommen unpolitisch werden solle. ${ }^{53}$ Dem setzt Golwalkar ein Verständnis von Religion entgegen, wonach diese eng mit der Gesellschaft verwoben sei und zugleich auf individuelle Bedürfnisse eingehe. Religion liefere die regulierenden Prinzipien, die sowohl für die Individuen als auch für die Gesellschaft insgesamt gedeihlich wirken sollen: „As many minds so many ways - this is the spiritual rule of true Religion. ${ }^{654}$ Eine solche Religion werde von den Hindus immer schon gelebt. Diese adressiere nicht nur das moralische und spirituelle Heil, sondern auch das materielle und politisch-soziale Wohlergehen. Daher sei eine Trennung von Religion und Gesellschaft bzw. Politik sowohl dem individuellen als auch dem nationalen Wohl abträglich. ${ }^{55} \mathrm{Im}$ Gegensatz zu den westlichen Religionen sei der Hinduism von Toleranz und

2u hindu-nationalistischen Konstruktionen der Nation als „Mutter" und die damit verbundenen Rollen für Frauen siehe Pandey, „Which of us are Hindus?", $259 \mathrm{ff}$.

51 Golwalkar, We or our Nationhood defined, 28.

52 Golwalkar, We or our Nationhood defined, 29.

53 Golwalkar weist darauf hin, dass es angesichts der zahlreichen religiösen Kriege in Europa nachvollziehbar ist, dass man Individualisierung und Religionsfreiheit sowie die Trennung von Religion und Polltik als Fortschritt gewertet habe. Das habe auch dazu geführt, dass man bei der Definition von "Nation“ den Faktor Religion als wenig relevant angesehen habe. Golwalkar, We or our Nationhood defined, $30 \mathrm{f}$.

54 Golwalkar, We or our Nationhood defined, 30.

55 An anderer Stelle erklärt Golwalkar, dass das klassische Konzept von dharma unter den Vorzeichen des westlichen Religionsbegriffs missverstanden worden sei, obwohl es sich von diesem unterscheide wie das Licht von der Dunkelheit: „Dharma or spirituality is not a dogma, but a view of life in its totality. [...] It is the sap of our national tree, the life-breath of our national entity." Golwalkar, Bunch of thoughts, 69. Er spricht auch vom "semitic effect" der Intoleranz, der alle „semitischen" Religionen aufgrund ihrer engen Dogmatik präge und der sich nun auch unter den Hindus ausbreite (ebd., 103-106). 
Offenheit für individuelle Wege geprägt, und auch das mache ihn zur einzig wahren Religion: „This great Hindu Race professes the illustrious Hindu Religion, the only religion in the world worthy of being so denominated, which in its variety is still an organic whole, capable of feeding the noble aspirations of all men, of all stages, of all grades, aptitudes and capacities [...], religion of which any sane man may be justly proud. Guided by this religion in all our walks of life, individual, social, political, the Race evolved a culture which despite the degenerating contact with the debased ,civilizations ' of the Mussalmans and the Europeans, for the last ten centuries, is still the noblest in the world. ${ }^{\circ 56}$ Die Einheit der Hindu-Nation dürfe nicht durch diejenigen unterminiert werden, die nicht dazu gehören. Golwalkar spricht sich gegen die Gewährung von Rechten für Minderheiten aus. Er lässt ihnen nur die Entscheidung zwischen einer Anpassung an die Hindu-Nation oder einer Randexistenz, die noch nicht einmal Bürgerrechte beinhaltet. ${ }^{57}$ Weiterhin behauptet Golwalkar den allumfassenden, quasi-transzendenten Charakter des Hindu-Seins auch dadurch, dass er erklärt, es lasse sich nicht definieren, was ein „Hindu“ sei: „We, the Hindus, have based our whole existence on God and therefore, it is probable that the Hindu Society developed in an all-comprehensive manner [...]. All the sects, the various castes in the Hindu fold, can be defined, but the term ,Hindu' cannot be defined because it comprises all. ${ }^{\circ 58}$ Es ist dieses Verständnis von Hinduismus und „Hindu-Sein“, welches die Grundlage dafür liefert, dass der Hindu-Nationalismus die Religion der Hindus als eine alles einschließende und zudem säkulare Religion propagieren kann. Hindu-Sein wird zur Norm des Indisch-Seins erhoben und die Hindu-Religion zu einer allumfassenden "Uber-Religion", in der alle Elemente von Religion enthalten seien.

Dieses Programm konnte jedoch nach der Erlangung der Unabhängigkeit und der Teilung Indiens im Jahre 1947 auf politischer Ebene keine Mehrheit hinter sich versammeln. Im Gegenteil: Die Hindu-Nationalisten fanden sich in der neugegründeten Indischen Republik in der Minderheitenposition wieder und ihre politischen Forderungen fanden kaum Niederschlag in der indischen

56 Golwalkar, We or our Nationhood defined, 48.

57 Golwalkar lehnt rechtliche Regelungen für den Schutz von Minderheiten ab und verweist u. a. auf die USA als ein Beispiel für eine Nation, die Assimilation fordere: „There are only two courses open to the foreign elements, either to merge themselves in the national race and adopt its culture, or to live at the sweet will of the national race." Golwalkar, We or our Nationhood defined, 55. Entsprechend müssten „non-Hindus“ wählen. Entweder sie adaptieren die Hindu-Kultur, lernen sie zu respektieren und ihre Intoleranz ihr gegenüber aufzugeben oder sie blelben im Land, wholly subordinated to the Hindu nation claiming nothing deserving no privileges far less any preferential treatment - not even citizens rights." Ebd., $55 \mathrm{f}$.

58 Golwalkar, Bunch of thoughts, 47.
Verfassung. Darin wurden Minderheitenrechte vorgesehen, und der Staat erklärte sich als religiös neutral (siehe unten). Weiterhin wurde nach der Ermordung von Gandhi im Jahre 1948 durch einen Attentäter, der dem RSS zumindest nahestand, diese Organisation zunächst verboten. Nach Aufhebung des Verbots im Jahre $1949 \mathrm{nahm}$ der RSS seine Aktivitäten wieder auf, und es wurde eine weitere Organisation gegründet, die zum politischen Arm für die Hindu-Nationalisten werden sollte und der Vorläufer der BJP wurde. Damit beginnt eine Geschichte der organisatorischen Expansion und politisch-kulturellen Mobilisierung, die mit dem Wahlsieg von Narendra Modi im Jahre 2014 ihren bisherigen Höhepunkt erreicht hat.

\section{Die „Familie“ der Hindutva-Organisationen (sarigh-parivār)}

Der Erfolg der Hindu-Nationalisten vor allem ab den 1980er Jahren beruht nicht allein auf der zuvor erörterten kulturalistisch-affektiven Hindutva-Ideologie, sondern auch auf einem breit aufgefächerten Spektrum von Organisationen, deren Vernetzung die praktische Umsetzung des Programms auf allen Ebenen betreibt. Den Kern bilden heute drei Organisationen, die sich komplementär zueinander verhalten: Der bereits erwähnte RSS und seine Frauenorganisation bilden die Kaderorganisation auf grassroot-level, die ihre Mitglieder in Trainingscamps zu Exerzitien versammelt und sich dabei unpolitisch gibt. Demgegenüber ist die BJP (Bharatiya Janta Party) eine Partei, die das Programm auf politischer Ebene umzusetzen sucht. ${ }^{59}$ Weiterhin gibt es seit 1964 die Višva Hindu Parisad (VHP; „Welt-Hindu-Rat"), die sich bemüht, die zahlreichen religiösen Gemeinschaften des Hinduismus unter einer Dachorganisation zusammenschließen. Sie alle bilden zusammen ein Netzwerk, das als Sangh Parivār (Familie der Organisationen) bezeichnet wird. ${ }^{60}$ Im Idealfall ergänzen sich die Aktivitäten der

$59 \mathrm{Zu}$ Geschichte und Programm der BJP siehe Bruce Graham, Hindu Nationalism and Indian Politics. The Origins and Development of the Bharatiya Janta Sangh. Cambridge: Cambridge University Press, 1990; Jaffrelot, The Hindu Nationalist Movement and Indian Politics. 1925 to 1990s; und die Beiträge in Hansen, Jaffrelot (eds.), The BJP and the Compulsions of Politics in India; für eine Analyse des Wahlkampfes von Narendra Modi im Jahre 2014 siehe Christophe Jaffrelot, „The Modi-centric BJP 2014 Election Campaign: New Techniques and Old Tactics“. Contemporary South Asia 23, 2 (2015), 151-166.

60 Weitere Organisationen werden dazu gezählt wie z. B. die im indischen Bundesstaat Maharashtra erfolgreiche Shiv Sena. Zur Geschichte dieses Organisationszusammenhangs siehe Basu et al., Khaki Shorts and Saffron Flags; Graham, Hindu Nationatism and Indian Politics; Jaffrelot, The Hindu Nationalist Movement and Indtan Politics; Thomas B. Hansen, The Saffron Wave. Democracy and Nationalism in Modem India. Princeton: Princeton University Press, 1999. 
„Familie“ gegenseitig, z. B. indem auf einer politischen Ebene Gesetze verabschiedet werden, die das religiöse-kulturelle Programm stützen bzw. umsetzen (etwa Anti-Konversionsgesetze, siehe unten). Umgekehrt dienen die Aktivitäten der sich unpolitisch darstellenden VHP und des RSS dazu, die Mobilisierung von politischen Mehrheiten für die BJP zu unterstützen.

Mit einem weitverzweigten Netzwerk von Anhängern auf lokaler Ebene bil det der RSS samt seiner Frauenorganisation die Kaderschmiede der Bewegung. ${ }^{61}$ Er unterhält in ganz Indien Trainingsplätze, wo sich die Mitglieder in militärischer Disziplin und Waffengebrauch üben. Der RSS übernimmt zudem zivile und humanitäre Aufgaben, z. B. Ordnungsaufgaben bei religiösen Festen oder Soforthilfe im Katastrophenfall. Auf jedem Utbungsplatz ist die safrangelbe Fahne aufgestellt, der sog. bhagvā dhvaj, die als Leitsymbol der Bewegung die Einheit aller Hindus symbolisieren soll. Die Fahne steht für die deśabhakti bzw. rāstrabhakti, der Liebe und Loyalität zur Nation. Hat einer die Ernsthaftigkeit seines Engagements bewiesen, so darf er reguläres Mitglied des RSS werden und folgenden Eid ablegen: „Remembering Almighty God and my forebears, I take this oath. For the betterment of my sacred Hindu religion, Hindu culture, and Hindu community, I will devote myself to the prosperity of my Holy Motherland. I swear that I shall serve the Rashtriya Svayam Sevak Sangh with my body, my mind, and my money. I will be faithful to this oath throughout my life. ${ }^{\text {"62 }}$ Man verpflichtet sich mit diesem Eid auf den Dienst am Mutterland. Letzteres wird in Form einer Göttin verehrt, als „Mutter Indien“, die Göttin Bhārat Mātā. Die Diener der Nation verstehen sich selbst auch als die dienenden Söhne der Göttin und treue Diener des Gottes Rāma, der für das Ideal einer Hindu-Herrschaft steht. Man trägt eine Khaki Shorts-Uniform, ${ }^{63}$ die weiblichen Mitglieder einen weißen Sari bzw. Salvar-Kamiz mit purpurfarbener Bordüre. Der RSS hat auch Schulen gegründet, deren Abschlüsse inzwischen denen der staatlichen Schulen gleichgestellt sind. ${ }^{64}$ Der RSS konzentriert sich somit auf die lokale und

61 Zur Geschichte und Organisation des RSS siehe Walter K. Andersen, Shridar D. Damle, The Brotherhood in Saffron. The Rashtriya Swayamsevak Sangh and Hindu Revivalism. New Delhi: Vistar Publications, 1987; Basu, et, al., Khaki Shorts and Saffron Flags; Jaffrelot, The Hindu Nationalist Movement and Indian Politics; Pralay Kanungo, The RSS's Tryst with Politics: From Hedgewar to Sudarshan. New Delhi: Manohar, 2002.

62 Zit. nach Andersen, Damle, The Brotherhood in Saffron, 98.

63 Basu et al., Khaki Shorts and Saffron Flags, 39, bemerken, diese Uniform sei „remarkably non-indigenous [... ] and copied from the British Indian police and army“. Nandy, „The Politics of Secularism and the Recovery of Religious Tolerance“, 187, bemerkt zur Uniform: „whatever the revivalist Hindu may seek to revive, it is not Hinduism“.

64 Die Anpassung der Schulbücher an hindu-nationalistische Lehren ist eines der Ziele, das von hindu-nationalistischen Organisationen nicht nur in Indien, sondern auch in anderen Ländern mit regionale Organisation der Hindus und die Ausbildung von Führungskräften Die lokalen Zentren werden überregional koordiniert, so dass inzwischen das Netzwerk des RSS ganz Indien durchzieht.

Der VHP geht es vor allem um eine Vereinheitlichung hinduistischer Lehren und Praktiken und damit um die Errichtung kirchenähnlicher Strukturen, die alle Hindus unter einem Dach versammeln. ${ }^{65}$ Diese Organisation hat dem Hindu-Nationalismus eine noch stärkere religiöse Grundierung gegeben, indem sie religiöse Themen und Symbole ins Zentrum ihrer Kampagnen rückt. Zudem ist sie eine wichtige Plattform für die internationale Vernetzung, insbesondere in der großen und z. T. auch sehr finanzkräftigen Hindu-Diaspora. Durch die Bildung einer gesamthinduistischen Organisation auf globaler Ebene will man ebenso geeint hinduistische Interessen vertreten wie es christliche Kirchen oder muslimische Verbände schon seit langem tun. Um das breite Spektrum religiöser Praktiken und religiös-philosophischer Lehrtraditionen zusammenzuführen, hat die VHP immer wieder versucht, einen Katalog von Texten, Lehren und Praktiken zu lancieren, der für alle Hindus verbindlich bzw. akzeptabel sein soll. 1984 wurde die militante Jugendorganisation Bajrang Dal als Teil der VHP gegründet, und 1991 die Frauenorganisation Durgā Vāhīni, die einerseits die Stärke von Frauen betont und diese auch im Waffengebrauch ausbildet, andererseits aber die Unterwerfung der Frauen unter das traditionelle hinduistische Frauenideal der treuen, dem Ehemann dienenden Ehefrau propagiert. ${ }^{66}$ Die angestrebte internationale Vernetzung war erfolgreich, und die VHP hat zahlreiche Ableger außerhalb Indiens (u. a. auch in Deutschland). Die VHP und ihr nahestehende Organisationen überwachen die Berichterstattung über den Hinduismus in den Medien und in akademischen Publikationen. Sie betreiben Internetseiten, auf denen sie nicht nur über ihre Aktivitäten informieren, sondern auch den Hinduis-

einer starken Hindu Diaspora intensiv verfolgt wird, siehe dazu Nandini Sundar, „Teaching to Hate RSS' Pedagogical Programme“. Economic and Political Weekly 39, No. 16 (2004), 1605-1612; und Peggy Froerer, „Disciplining the Saffron Way: Moral Education and the Hindu Rashtra“. Modern Asian Studies 41, 5 (2007), 1033-1071.

$65 \mathrm{Zu}$ Geschichte und Programm der VHP siehe Basu et al., Khaki Shorts and Saffron Flags, Christophe Jaffrelot, „The Vishva Hindu Parishad: A Nationalist but Mimetic Attempt at Federating the Hindu Sects". In Vasudha Dalmia, Angelika Malinar, Martin Christof (eds.), Charisma and Canon: Essays on the Religious History of the Indian Subcontinent. Oxford, New Delhi: Oxford University Press, 2001, 388-412; Manjari Katju, The Vishva Hindu Parishad and Indian Politics. Hyderabad: Orient Longman, 2003.

66 Zur Rolle und zu den Aktivitäten von Frauen in hindu-nationalistischen Organisationen siehe die Beiträge in Tanika Sarkar (ed). Women and the Hindu Right: A Collection of Essays. New Delhi Kali for Women, 1995; und Manisha Sethi, „Avenging Angels and Nurturing Mothers: Women in Hindu Nationalism“. Economic and Political Weekly 37, No. 16 (2002), 1545-1552. 
mus, seine elementaren Lehren und Praktiken erklären. ${ }^{67}$ Die VHP war und ist auch maßgeblich an den Kampagnen zur Rückführung von heiligen Stätten der Hindus beteiligt, die während der muslimischen Herrschaft zerstört oder enteignet worden seien. So forderte sie etwa die Rückgabe eines alten Hindu-Tempels in Ayodhya, der als Geburtsstätte des Idealkönigs und Gottes Rāma angesehen wurde. An dessen Stelle stand nun nach Ansicht der Hindu-Nationalisten die Babri-Moschee auf der "heiligen Erde, auf der Gott Rāma geboren wurde“ (rāmjanmabhūmi), und sie forderten von den Muslimen eine Entschuldigung. Die Agitation führte 1992 zur Zerstörung der Moschee durch Hindu-Nationalisten. ${ }^{68}$ Seither ist es immer wieder zu militanten Agitationen und gewalttätigen Ausschreitungen gekommen, die zahlreiche Todesopfer forderten.

Eines der zentralen Mobilisierungsfelder der hindu-nationalistischen Organisationen im postkolonialen Indien ist die Kritik an der Benachteiligung der Mehrheitsreligion der Hindus gegenüber den anderen Religionen durch den angeblich nur „pseudo-säkularen“ indischen Staat. Die zuvor erörterte Interpretation von „Hindu-Sein“ und Hinduismus in den Schriften von Savarkar und Golwalkar liefert die ideologische Grundlage für diese Selbstdarstellung.

\section{Hindu-Nationalismus und der säkulare indische Staat}

Die Hindu-Nationalisten präsentieren sich nicht als Gegner eines modernen Staatswesen, sondern sie stellen sich im Gegenteil als die wahren Verfechter von demokratischem Mehrheitsprinzip und Säkularismus dar. Ihnen geht es darum, der Hindu-Mehrheit bzw. dem Hindu-Sein im eigenen Land zu ihrem "angestammten“ Recht zu verhelfen. Der Hinduismus wird dabei zur „säkularen" Religion erhoben. Die hindu-nationalistische Propaganda richtet sich gegen die in der indischen Verfassung verankerten Rechte von Minderheiten und dagegen, wie der indische Staat - obgleich zu Neutralität verpflichtet - in das religiöse Leben der Hindus eingreife. Hintergrund dieser Kritik ist, dass nach der Unabhängigkeit die Prinzipien eines religionsneutralen indischen Staates maßgeblich wurden und keine Staatsreligion verankert wurde (wie etwa im durch die Teilung geschaffenen Pakistan). Gleichwohl führte die indische Republik die Religionspolitik der Kolonialzeit insofern fort, als sie „Reform“ und „Fortschritt“ zu Leitbegriffen staatlicher Politik erhob. Daher dürfen Religionen nicht

67 Siehe dazu Rowena Robinson, „Religion on the Net: An Analysis of the Global Reach of Hindu Fundamentalism and its Implications for India“. Sociological Bulletin 50, 2 (2001), 236-251.

68 Siehe dazu Sarvepalli Gopal (ed.), Anatomy of a Confrontation - The Babri Masjid Ramjanmabhumi issue. New Delhi: Penguin, 1993; und die Beiträge in Pandey (ed.), Hindus and Others. gegen grundlegende, durch die Verfassung geschützte Rechte verstoßen oder den sozialen Fortschritt behindern. Zugleich garantiert die indische Verfassung Religionsfreiheit (Hindi: dharm kì svatantratā) und verbietet sowohl die Diskriminierung als auch die Privilegierung von Einzelnen oder ganzen Gruppen im Namen der Religion. ${ }^{69}$ Die Religionen wurden zugleich auf den übergeordneten rechtlichen Rahmen und das säkulare Selbstverständnis des indischen Staates bezogen. ${ }^{70}$ Form und Struktur dieses Säkularismus führten zu intensiven Debatten, in denen es vor allem um zwei Modelle geht. Nach dem einen Modell wird "Säkularismus“ als Neutralität des Staates gegenüber allen Religionen verstanden (sarvadharmanirapekșatva) und beinhaltet eine deutliche Trennung von Staat und Religion. Nach dem anderen Modell soll sich der Staat zu einer wohlwollenden Respektierung aller Religionen (sarvadharmasamabhäv) verpflichten. Die Debatten über den „Säkularismus“ des indischen Staates halten an. ${ }^{71}$ Festzuhalten ist, dass Säkularismus in Indien weder eine vollkommene Trennung von Staat und Religion beinhaltet noch eine formelle Gleichbehandlung aller Religionen. In genau diesem Spannungsfeld haben sich die Hindu-Nationalisten immer wieder als Vertreter des wahren Säkularismus darzustellen versucht, indem sie die den religiösen Minderheiten eingeräumten Rechte als Ungleichbehand. lung bzw. „Diskriminierung der Hindu-Mehrheit“" brandmarkten. Die BJP fordert in ihren Wahlprogrammen die Umsetzung des o.g. Modells der respektvollen Gleichbehandlung aller Religionen, was als „positive secularism“ bezeichnet wird. ${ }^{72}$ Zugleich wird dieser „positive Säkularismus“ mit dem „Hindu-Sein“ bzw. dem Hinduismus gleichgesetzt. Ein näherer Blick auf den rechtlich-politischen Kontext mag diese Konstellation erklären.

Die indische Verfassung garantiert allen Bürger zwar die freie Ausübung ihrer Religion, zugleich behält sich der indische Staat jedoch regulierende Eingriffsmöglichkeiten vor, wenn dabei die öffentliche Ordnung, die Moral oder die Gesundheit gefährdet wird (Artikel 25 der indischen Verfassung). Weiterhin

69 Siehe dazu Angelika Malinar, „Religionsfreiheit und Hinduismus“. In Hans-Georg Ziebertz (Hg.), Religionsfreiheit. Positionen, Konflikte, Herausfordenungen. Wïrzburg: Echter, 2015, 183-210. 70 Das Wort , secular" erscheint in der 1949 verabschiedeten Verfassung noch nicht, sondern wird erst 1976 implementiert.

71 Siehe dazu u. a. Daniel E. Smith, India as a Secular State. Princeton: Princeton University Press, 1963; Cossman, Kapur, „Secularism“; dies., „Secularism's last Sigh? The Hindu Right, the Courts and India's Struggle for Democracy“. Harvard Intemational Law Joumal 38,1 (1997), 113-170; Cassie S. Adcock, The Limits of Tolerance: Indian Secularism and the Politics of Religious Freedom. Oxford: Oxford University Press, 2014; sowie die Beiträge in Robert D. Baird, (ed.), Religion and Law in Independent India. New Delhi: Manohar, 1993; und Rajeev Bhargava (ed.), Secularism and its Critics. Oxford: Oxford University Press, 1998.

72 Siehe Cossman, Kapur, „Secularism“, 2622. 
sind Gesetze möglich, die dem Staat erlauben, sog. „säkulare“ Aktivitäten religiöser Gemeinschaften zu regulieren. Der Staat behält sich somit vor, in die wirtschaftlichen, sozialen oder politischen Aktivitäten religiöser Gemeinschaften einzugreifen. ${ }^{73}$ Bei den in der Verfassung als "Hindu“ bezeichneten Religionen $^{74}$ wird zudem ein besonderer Reformbedarf ausgewiesen. In der Verfassung wird mehrfach auf „Hindu“-Institutionen und -Praktiken Bezug genommen, um besondere Vorkehrungen zu formulieren (Abschaffung von „Unberührbarkeit“, Maßnahmen für „temple entry“ für alle Hindus usw.). Der Staat darf eingreifen, um hier für „social welfare and reform“ zu sorgen. Der Rechtshistoriker Marc Galanter bezeichnet diesen Teil der indischen Verfassung als „a charter for the reform of Hinduism". ${ }^{75}$ Darin zeigt sich die anhaltende Wirkung der kolonialen Debatten um den Hinduismus, der von der Kolonialregierung sowie von einigen Vertretern des Hinduismus selbst als eine besonders reformbedürftige Religion angesehen wurde. Damit gilt die säkulare Neutralität des Staates nicht für alle Religionen in gleicher Weise. Das zeigt sich auch darin, dass religiösen Minderheiten ein besonderer Schutz gewährt wurde (ein Sachverhalt, der nicht zuletzt dem Trauma der Teilung Indiens geschuldet ist). Dabei spielt das Privat- bzw. Familienrecht eine besonders wichtige Rolle.

Den religiösen Minderheiten, wie Muslimen und Christen, wurde erlaubt, ihre familiären Angelegenheiten nach ihren eigenen Rechtsordnungen zu regeln, also gemäss Sharia bzw. Kirchenrecht. Das führte dazu, dass bis heute die Gleichheit vor dem Gesetz für Inder und Inderinnen nur im Strafrecht gilt, aber nicht im Privat- bzw. Familienrecht. Ein für alle indischen Staatsbürger geltendes Zivilrecht (civil code) wurde in Artikel 44 der Verfassung als ein wünschenswerter Auftrag an den Gesetzgeber formuliert, nicht aber als eine bindende Verpflichtung. Bis heute gibt es deshalb unterschiedliche Zivilgesetze für Inder und Inderinnen auf Basis ihrer Religionszugehörigkeit. Eine einheitliche Gesetzgebung

73 Nach Dhavan führte das zu immer mehr staatlichen Kontrollen und rechtlichen Regelungen „By enlarging, but not defining, notions of secular management, public order, morality and health, almost any part of religious activity is subject to control. This is manifested in the virtual takeover of the manament of religious institutions, the scheduling and re-routing of religious processions and public celebrations, and the re-interpretation of the significance of religious practices by agencies of the State, including the Judiclary." Rajeev Dhavan, „Religious Freedom in India“. The American Journal of Comparative Law 35, 1 (1987), 209-254; siehe auch Ronojoy Sen, Articles of Faith, Religion, Secularism and the Indian Supreme Court. New Delhi: Oxford University Press, 2010; und Marc Galanter, „Hinduism, Secularism, and the Indian Judiciary“. Philosophy East and West 21, 4 (1971), 467-487.

74 Nach Artikel 25 der indischen Verfassung schließt die Bezeichung „Hindu“ auch Sikhs, Jainas und Buddhisten ein.

75 Galanter, „Hinduism, Secularism, and the Indian Judiciary“, 477. gibt es nur im Strafrecht. So gilt z.B. die Sharia für alle privatrechtlichen Belange indischer Muslime, hat aber keine strafrechtliche Relevanz. ${ }^{76}$ Im Unterschied zu den religiösen Minderheiten wurden in den 1950er Jahren die Hindus einer allgemeinen zivilrechtlichen Gesetzgebung unterstellt. Ein wichtiges Ziel dieser Gesetzgebung war die Beendigung der Diskriminierung und Unterdrückung von Frauen. Zunächst wurde 1955 der Hindu Marriage Act verabschiedet, 1956 folgten der Hindu Succession Act, der Hindu Minority and Guardianship Act sowie der Hindu Adoption and Maintenance Act. Dabei wurden Regelungen eingeführt, die nach den alten Hindu-Rechtstexten, den Dharmaśāstras, nicht erlaubt waren, wie etwa die Scheidung oder eine neue Festlegung des Heiratsalters, die Praktiken der Kinderheirat unterminieren sollte. Weiterhin wurde Polygynie verboten, die in einigen Regionen und bei bestimmten sozialen Gruppen auch unter Hindus keineswegs unüblich war. Zudem wurden die regional unterschiedlichen Regelungen im Erbfall vereinheitlicht und Frauen generell ein Erbrecht zugesprochen. Hindu-Witwen wurde das Adoptionsrecht eingeräumt. Diese Gesetzgebung entsprach zwar dem Reformprogramm des Staates, unterstrich aber die Tatsache, dass staatlich implementierte zivilrechtliche Regelungen nur für die Hindus, aber - aus den o.g. genannten Gründen - nicht für die religiösen Minderheiten gelten.

Sowohl orthodoxe Hindus als auch Hindu-Nationalisten protestierten, aus unterschiedlichen Gründen, gegen diese Gesetzgebung. Während die orthodoxen Gruppen die Zerstörung der Hindu-Traditionen beklagten, sahen die HinduNationalisten darin in erster Linie eine massive Benachteiligung der HinduMehrheit. Die Proteste der orthodoxen Hindus blieben relativ folgenlos, die modernistisch-demokratisch anmutende Position der Hindu-Nationalisten war jedoch paradigmatisch für ihre Mobilisierungsstrategie. Das unterstreicht nochmals, dass es den Hindutva-Verfechtern keineswegs um eine Rückkehr zu alten Hindu-Traditionen und -Texten geht, sondern vielmehr darum, sich als Repräsentanten einer Mehrheit darzustellen, deren Religion immer schon säkular gewesen sei. ${ }^{77}$ In den folgenden Jahrzehnten wurde die Kritik an der unterschiedlichen zivilrechtlichen Behandlung der Religionen von den Hindu-Nationalisten in die These umgemünzt, dass der indische Staat die „Mehrheitsreligion“ benachteilige und sich daher undemokratisch und nicht säkular verhalte. Weder könne von Neutralität die Rede sein noch von Gleichbehandlung, da die Hindu-Mehrheit durch das staatliche Festhalten an den Rechten für die Minderheitsreligionen

76 Zu dieser rechtlichen Konstellation siehe die Aufsätze in Baird (ed.), Religion and Law in Independent India; und Gerald James Larson (ed.), Religion and Personal Law in Secular India. Bloomington: Indiana University Press, 2001.

77 Siehe Cossman, Kapur, „Secularism“. 
diskriminiert werde. Nicht zuletzt im Zuge der 1976 unter Indira Gandhi in Kraft gesetzten Definition der Indischen Republik als „säkular“ sowie in den 1980er Jahren durch den sog. „Shah Bano Case" wurde die Kritik immer lauter. In dem letztgenannten Gerichtsstreit versuchte die von ihrem Ehemann nach ShariaRecht geschiedene Muslimin Shah Bano Unterhaltsansprüche vor staatlichen Gerichten durchzusetzen. Nach mehreren Instanzen sprach der indische Supreme Court Shah Bano schließlich Unterhaltszahlungen zu, obwohl ihr diese nach der Sharia nicht zustanden. Das führte Mitte der 1980 Jahre dazu, dass von der indischen Regierung eigens ein Gesetz verabschiedet wurde, das muslimischen Frauen im Falle der Scheidung andere Rechtswege versperrte (Muslim Women Protection of Rights on Divorce Bill). Danach wurde es für die Regierung schwierig, dem von verschiedenen Seiten erhobenen Vorwurf des „Schein-Säkularismus“ entgegenzutreten. ${ }^{78}$

Die hindu-nationalistischen Organisationen wurden nicht müde darauf hinzuweisen, dass sich der indische Staat nur den Hindus gegenüber „säkular“ zeige, während Christen und Muslime weiterhin ihren Traditionen folgen dürfen. Sie lancierten nun zunehmend militanter ihre Vorstellung, dass der Hinduismus bzw. Hindutva der ,wahre Säkularismus“ sei. Denn der Hinduismus, der das Wesen der Hindu-Kultur manifestiere, habe schon immer alle Glaubensrichtungen gleichbehandelt. Daher würden sich mit der Errichtung eines Hindu-Staates (Hindu Rashtra), Säkularismus und Gleichheit von selbst verwirklichen. Hinduismus und Hindutva werden zunehmend gleichgesetzt und als Basis wahrer Toleranz dargestellt. So behauptet etwa RSS-Führer Golwalkar: „if by secularism is meant that the State should not be tagged to any particular creed and that all faiths should be equally respected, then this again would be another name of the Hindu tradition. In fact, Hindu tradition goes far beyond the western concept of ,tolerance' which implies that the faith which ,tolerates' is superior to the other. With us, all faiths are equally sacred. [...] Hinduism is secularism in its noblest sense. ${ }^{\text {"79 }}$ Damit wird die kulturalistisch-affektive Deutung von Hindutva mit dem Hinduismus als seiner säkularen Religion zur Norm des Zusammenlebens in Indien erhoben. Eine Reklamation von religiösen Minderheitenrechten bekundet demnach „Intoleranz“ gegenüber der säkularen Mehrheitsreligion und sei zudem

78 Zum „Shah Bano Case“ und den Folgen siehe u. a. Ashgar Ali Engineer (ed.), The Shah Bano Controversy. Hyderabad: Orient Longman, 1987; Nawaz B. Mody, „The Press in India: The Shah Bano Judgement and its Aftermath“. Asian Survey 27,8 (1987), 935-53; Shioban Mullally, „Feminism and Multicultural Dilemmas in India: Revisiting the Shah Bano Case". Oxford Journal of Legal Studies 24,4 (2004), 671-692.

79 Madhav Sadashiv Golwalkar, From Red Fort Grounds, 1965, zit. nach Cossman, Kapur, „Secularism's last sigh?" 148. Vgl, auch Golwalkar, Bunch of thoughts, 127. undemokratisch. Solche Intoleranz zeige sich auch in Praktiken der Konversion. So stellt Madhukar Dattatraya Deoras, auch Balasaheb genannt, (1915-1996), der Nachfolger von Golwalkar als Führer des RSS, fest: „If secularism means treating all religions on an equal footing, proselytisation and secularism can't go together. Those who believe in conversion do so because they feel that their religion is superior to all others. Their organisations therefore cannot claim to be secular. Hinduism, on the other hand, does not believe in conversions and Hindus have never been proselytisers. As such, organisations of Hindus alone can be truly secular. ${ }^{* 80}$

Entsprechend sehen die Vertreter des Hindu-Nationalismus in der Konversion in erster Linie ein Instrument, das Christen und Muslime einsetzen, um ganz gezielt sog. „schwache“, d. h. arme und benachteiligte hinduistische Bevölkerungsgruppen auf ihre Seite zu ziehen und dadurch dem Hinduismus $\mathrm{zu}$ schaden. ${ }^{81}$ In diesem Zusammenhang ist zumeist von „Zwangskonvertierungen“ oder „Gruppenkonvertierung“ die Rede, und es wird suggeriert, dass dabei „unlautere“ Methoden eingesetzt werden, wie etwa die Zusage materieller Vorteile. Die durch diese Darstellung ausgelösten politischen Debatten führten dazu, dass in mehreren indischen Bundesstaaten sog. „Anti-Konversionsgesetze" erlassen wurden. ${ }^{82}$ Diese Gesetze stellen Konversionen, die auf Anwendung von Zwang oder Gewalt, Uberredung, Zusage finanzieller Vorteile oder Betrug basieren, unter Strafe. Das Strafmaß wird z. T. nach dem sozialen Status der Konvertierten bemessen, d.h. die Konversion von Frauen z.B. wird härter bestraft. In einigen Bundesstaaten wird verlangt, dass Konversionen vorher bei den staatlichen Behörden angemeldet werden. Zudem wird von Vertretern des Hindu-Nationalismus bestritten, dass es ein Recht gibt, aus dem Hinduismus „auszutreten“ bzw. zu einer der sog. „Minderheitenreligionen“ zu konvertieren, während das Recht, zum Hinduismus zu (re-)konvertieren, unstrittig scheint. ${ }^{83} \mathrm{Zu}$ Recht stellen Brenda Cossman und Ratna Kapur fest, dass es dem Hindu-Nationalismus darum

80 Balasaheb Deoras, Answers Questions. Bangalore: Sahitya Sindhu, 1984, 54. An elner anderen Stelle behauptet Deoras, dass das Bestehen des säkularen Staates garantiert sei, weil die Hindus die Mehrheit bilden, „in whose blood secularism is there“ (ebd., 4).

$81 \mathrm{Zu}$ der sich darin spiegelnden paternalistischen Haltung gegenuiber Frauen und unteren Kasten siehe Laura Dudley Jenkins "Legal Limits on Religious Conversion in India“. Law and Contemporary Problems 71, No. 2 (2008), 109-127.

82 In neuerer Zeit sind zu nennen: Gujarat 2003, Himachal Pradesh 2006, Chattisgarh 2006. In weiteren drei Bundesstaaten sind ältere Anti-Konversionsgesetze in Kraft (Odisha, Madhya Pradesh, Arunachal Pradesh); siehe Tariq Ahmad, „State Anti-Conversions Laws in India. The Law Library of Congress. Report for Congress: LL File No. 2017-014600", https://www.loc.gov/law/help/reports/pdf/2017-014600.pdf, für eine Übersicht und historische Erläuterung.

83 Kürzlich verabschiedete „Anti-Konversions-Gesetze“ scheinen dieser Interpretation Rechnung 
gehe, „to appropriate secularism for its own rather non-secular purposes" ${ }^{84}$ Religionszugehörigkeit wird durch eine kulturalistisch fundierte Mitgliedschaft in der einen Hindu-Nation substituiert. In dieser Instrumentalisierung von Religion bleibt religiöse Vielfalt ein Signum des Hinduismus, aber er wird zugleich in den hindu-nationalistischen Organisationen vereinheitlicht und uniformiert. ${ }^{85}$

Entsprechend einseitig ist die hindu-nationalistische Auslegung des Mehrheitsprinzips der Demokratie, indem die Lebensweise und Religion der HinduMehrheit zum Maßstab, zur „nobelsten“ Form von Kultur und Religion in Indien erhoben wird. Ein anderer Vertreter des Hindutva-Programms formuliert die Position in einem Zeitungsartikel von 1990 wie folgt: „Democracy in normal parlance means the rule of the majority. In every single democratic country, it is the majority culture whose ideals and values of life are accepted as the national ethos by one and all. [...] No religious group can claim any exclusive rights and privileges to itself. “86 Der in dieser Interpretation implizierte „majoritarianism“ zeigt sich auch darin, dass die andere Seite von Demokratie und Verfassungsrechten, nämlich Schutz von Minderheiten gegenüber einem rein formell ausgelegtem Gleichheitsgrundsatz sowie Freiheitsrechte (wie Religionsfreiheit), weniger bzw. gar kein Gewicht mehr haben soll. ${ }^{87}$ Diverse Gerichtsurteile in den 1990er Jahren zeigen den Erfolg der hindu-nationalistischen Strategie, die darauf zielt, ein kulturell-religiöse definiertes "Hindu-Sein" als Norm des „Indisch-Seins“ durchzusetzen und dieses wiederum mit dem Hinduismus gleichzusetzen. Durch diese Gerichtsentscheidungen sehen die Hindu-Nationalisten ihre (von Savarkar bereits 1923 formulierte) Sicht bestätigt, ${ }^{88}$ dass der Hinduismus zum „Hindu-Sein“

zu tragen. Das gilt z. B. für das in Arunachal Pradesh verabschiedete Gesetz, dass Konversion als „renouncing an indigenous faith" definiert und verbietet. Die Einseitigkeit der Gesetzgebung wird in kritischen Analysen betont; siehe South Asia Human Rights Documentation Centre, „AntiConversion Laws: Challenges to Secularism and Fundamental Rights". Economic and Political Weekly 43, No. 2 (2008), 63-69, 71-73; und Sumit Sarkar, „Conversions and Politics of Hindu Right“. Economic and Political Weekly 34, No. 26 (1999), 1691-1700.

84 Cossman, Kapur, "Secularism", 2620.

85 Nandy stellt fest; ,The goal of those holding such an instrumental view of religion has always been to homogenize their co-believers into proper political formations, and, for that reason, to eliminate that parts of religion [...] which threaten to legitimize diversities, inter-faith dialogue and theological polycentrism. " Nandy, „The Politics of Secularism and the Recovery of Religious Tolerance“", $182 \mathrm{f}$.

86 H. V. Seshadri, in „Organiser“, 4.2.1990; zit. nach Cossman, Kapur, „Secularism’s last Sigh?“, 147.

87 Cossman, Kapur, „Secularism“

88 Zum juristischen Erfolg dieser Strategie und einer Kritik dieser Urteile siehe Cossman, Kapur, „Secularism“; und dies., „Secularism's last Sigh?“; sowie Sen, Articles of Faith, Religion, Secularism and the Indian Supreme Court. gehöre und er zudem keine Religion im westlichen Sinne sei, sondern vielmehr ein „way of life“. Hindutva wird in diesen Urteilen mit Hinduismus gleichgesetzt und beides wird als Bezeichnung der Lebensweise und Kultur der Inder angesehen. In dem Versuch, das „Hindu-Sein“ als säkular zu propagieren, wird die Religion zugleich immer wieder neu als Merkmal von Hindutva profiliert, so dass es zu folgendem Effekt kommt: "In the contemporary political terrain hindutva thus continues to be a political category that is distinct from the religions of Hinduism, but which relies on religion in constituting the political category of Hindu. ${ }^{89}$ Das Religionsverständnis der Minderheiten, aber auch von Hindus, die sich mit der Hindutva-Ideologie nicht anfreunden können oder wollen, gerät unter Druck. Sie sehen sich zunehmend mit der Forderung konfrontiert, sich dem Lebensstil und den Werten der Hindu-Mehrheit anzupassen. Das zeigen nicht nur die o.g. Anti-Konversionsgesetze, sondern auch Maßnahmen wie das Verbot, Kühe zu Schlachtzwecken zu handeln (,beef-ban“), welches die Regierung Modi verhängte, da es die Gefühle der Hindus verletze, denen die Kuh heilig sei. ${ }^{90}$

\section{Schlussbemerkung}

Das im Hindu-Nationalismus propagierte Programm eines religionsbasierten und zugleich mit voluntaristischen Elementen versehenen Kulturnationalismus namens „Hindutva“ unterscheidet sich von anderen Interpretationen des Hinduismus in der Moderne dadurch, dass die Forderung nach einer religiösen Fundierung des gesellschaftlichen Zusammenlebens mit modernen Ideen der Nation, einer demokratischen Legitimation durch „Mehrheit" sowie von Säkularismus verbunden wird. Um einer als benachteiligt dargestellten Hindu-Mehrheit $\mathrm{zu}$ ihrem Recht zu verhelfen, sei es notwendig, sich auf die Traditionen der Stärke zu besinnen, um die Hindu-Nation in einem Hindu-Staat (Hindu Rashtra) zu ihrer wahren Größe zu führen. Alle Hindus werden zur Selbstbehauptung gegenüber den Feinden des Hinduismus aufgerufen. Der Hinduismus wird von den Hindu-Nationalisten als eine Religion präsentiert, die viel besser als der Staat die Prinzipien von Demokratie und Säkularismus vertrete und diese vor den Ansprüchen weniger toleranter Religionen (wie Islam und Christentum) schütze. Nach Ansicht der Hindu-Nationalisten bedeutet Hindutva in religiös-kultureller Hinsicht nichts anderes als der säkulare Hinduismus im Sinne der gelebten indi-

89 Cossman, Kapur, „Secularism", 2619

90 Dieses Verbot wurde zwar 2017 vom indischen Verfassungsgericht aufgehoben, aber weitere Initiativen zum „Kuhschutz" wurden angekündigt. 
schen Kultur und Lebensform. Der den Hindus zugeschriebene Universalismus zeige sich im dem breiten Spektrum von religiösen Lehren und Praktiken, das viel Platz für individuelle Spiritualität biete. Diese Darstellung lässt das Insistieren auf religiöser Differenz bzw. ein Bekenntnis zu einer nicht-Hindu-Religion wie einen unmodernen, nicht-säkularen Anachronismus erscheinen. Auch Muslime und Christen, so sie sich entscheiden, die Hindu-Nation zu lieben und zu verehren, sollten - so die Hindu-Nationalisten - kein Problem haben, sich dieser säkularen Religion anzuschließen bzw. in ihr aufzugehen. Im Namen von Demokratie und Säkularismus wird eine Form der Anpassung an die Mehrheit propagiert, die Freiheitsrechte einzuschränken droht. Zugleich präsentiert die Regierung Modi gegenüber der Weltöffentlichkeit immer wieder auch die sanfte Seite des „Hindu-Seins“, bekundet das Interesse Indiens, zum friedlichen Miteinander auf globaler Ebene beizutragen. Kaum zufällig hat Modi den Yoga zum Emblem dieser Botschaft gemacht, denn er bietet eine Plattform für die globale Positionierung Indiens und des Indisch-Seins im Sinne von Hindutva. Damit verleiht er dem Hindu-Nationalismus einen moderaten Anschein, der vor allem auf Auslandsreisen als eine Form der „soft power" präsentiert wird. Es ist von einer „Yoga-Diplomatie“ die Rede, deren Früchte sich nicht allein in der eingangs erwähnten Einsetzung des „International Yoga Day“ durch die Vereinten Nationen zeigen, sondern z. B. auch in der Schaffung von Yoga-Instituten im Ausland. ${ }^{91}$ Ob diese sanftere Präsentation des Hindu-Nationalismus jedoch insgesamt eine Mäßigung in der Politik gegenüber Minderheiten und in der Durchsetzung von Hindu-Werten bedeutet, ist offen. Die Ernennung des als besonders radikal geltenden Yogi Adityanath zum Ministerpräsidenten des bevölkerungsreichsten Bundesstaates Uttar Pradesh nach dem hohen Wahlsieg der BJP im Jahre 2017 deutet eher auf das Gegenteil. Yogi Adityanath unterhält eine eigene Jugendorganisation (Hindu Yuva Vahini), die auch vor gewalttätigen Aktionen gegen die sog. „Feinde“ der Hindus nicht zurückschreckt. ${ }^{92}$ Vieles spricht dafür, dass die Bemühungen um eine weitere Umsetzung der Hindutva-Programmatik zur Schaffung eines Hindu-Staates weitergehen werden. Damit stehen die Religionsfreiheit und andere Grundrechte ebenso auf dem Spiel wie der religiöse Pluralismus, der die indische Religionsgeschichte über weite Phasen ebenso charakterisiert wie das gegenwärtige Indien.

91 Ein Beispiel ist die Gründung einer Yoga-Schule an der Minzu-Universität in Yunnan im Anschluss an Narendra Modis Staatsbesuch in China im Jahre 2015; siehe Aavriti Gautam, Julian Droogan, „Yoga soft power: how flexible is the posture?“. The Joumal of International Communication 24, 1 (2018), 18-36.

92 Siehe Christophe Jaffrelot, „India's Democracy at 70: Toward a Hindu State?". Joumal of Democracy 28, 3 (2017), 52-63, hier 58

\section{Armin Nassehi}

\section{Geschlecht, Geschlechtlichkeit, Religion. Woran liegt die Sexbesessenheit des Religiösen?}

Religiöse Moral- und Kontrollvorschriften orientieren sich gerne am Sexuellen: Patriarchalische Rechtfertigungsformen, aber weniger Männer- als Frauenbilder, die Regulierung von Sexualpraktiken und -pflichten als Herrschaftsinstrument, Heiligung ehelicher Verbindungen, Ehe-(nicht: Sexualitäts-)Losigkeit für Geistliche, Homosexualität - all das sind die üblichen verdächtigen Themen, um die sich die Fixierung auch der öffentlichen Diskussion um die Sexualisierung des Religiösen dreht. Genau genommen sind diese Themen aber nicht wirklich aufregend, schon weil sich in den klassischen Quellen etwa der drei monotheistischen Weltreligionen durchaus Regulierungen von Sexualpraktiken finden lassen, die empirische Ausgestaltung aber historisch, kulturell und milieumäßig nicht nur zwischen, sondern auch innerhalb dieser Religionen so stark variiert, dass man nicht weiß, ob man dann über Religion redet oder über allgemeine kulturgeschichtliche Veränderungen.

Ich möchte einen anderen Argumentationsweg bestreiten, der zugegebenermaßen kaum historisch und wenig empirisch gesättigt ist, sondern ein theoretisches Argument entfalten will. Die These lautet, dass alle drei Komponenten meiner Fragestellung: Geschlecht, Sexualität und Religion eine strukturelle Gemeinsamkeit teilen: Sie laborieren je unterschiedlich an einer merkwürdigen Unterscheidung zwischen Wahrnehmung und Kommunikation, die sie praktisch entfalten müssen. Diese Gemengelage macht jene Konzentration des Religiösen auf Geschlechtlichkeit und Sexualität erst verstehbar. Womöglich wird in der Dekonstruktionsarbeit unserer kulturellen Chiffren der Eigensinn der Wahrnehmung systematisch unterschätzt, was erhebliche Konsequenzen für ein angemessenes Verständnis von Geschlechtlichkeit und Sexualität hat und auch die Sonderform religiöser Rede bestimmt.

Die folgenden Utberlegungen sind kaum abgeschlossen, vielmehr vermessen sie eher einen Argumentationsweg, der genauere Forschung erst anleiten müsste. Die theoretischen Andeutungen aber könnten wenigstens eine Antwortrichtung anzeigen, in welche Richtung gedacht werden muss, warum es gerade Sexualität ist, die für religiöse Regulierung so attraktiv ist, und warum es die Unterscheidung von Wahrnehmung und Kommunikation ist, die eine gewisse Verwandtschaft zwischen Religion und Sexualität stiftet. Gelingen diese theoretischen Andeutungen, wäre daraus ein Forschungsprogramm zu entwickeln. 